University of Nebraska - Lincoln

DigitalCommons@University of Nebraska - Lincoln

USGS Staff -- Published Research

US Geological Survey

2015

Late Quaternary sea-level history and the antiquity of mammoths (Mammuthus exilis and Mammuthus columbi), Channel Islands National Park, California, USA

Daniel R. Muhs

U.S. Geological Survey, dmuhs@usgs.gov

Kathleen R. Simmons

U.S. Geological Survey

Lindsey T. Groves

Natural History Museum of Los Angeles County

John McGeehin

US Geological Survey

R. Randall Schumann

U.S. Geological Survey

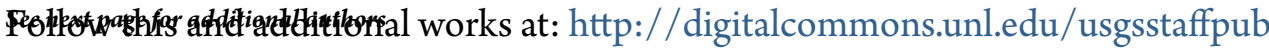

Part of the Geology Commons, Oceanography and Atmospheric Sciences and Meteorology Commons, Other Earth Sciences Commons, and the Other Environmental Sciences Commons

Muhs, Daniel R.; Simmons, Kathleen R.; Groves, Lindsey T.; McGeehin, John; Schumann, R. Randall; and Agenbroad, Larry D., "Late Quaternary sea-level history and the antiquity of mammoths (Mammuthus exilis and Mammuthus columbi), Channel Islands National Park, California, USA" (2015). USGS Staff -- Published Research. 930.

http://digitalcommons.unl.edu/usgsstaffpub/930

This Article is brought to you for free and open access by the US Geological Survey at DigitalCommons@University of Nebraska - Lincoln. It has been accepted for inclusion in USGS Staff -- Published Research by an authorized administrator of DigitalCommons@University of Nebraska - Lincoln. 


\section{Authors}

Daniel R. Muhs, Kathleen R. Simmons, Lindsey T. Groves, John McGeehin, R. Randall Schumann, and Larry D. Agenbroad 


\title{
Late Quaternary sea-level history and the antiquity of mammoths (Mammuthus exilis and Mammuthus columbi), Channel Islands National Park, California, USA
}

\author{
Daniel R. Muhs ${ }^{\text {a,* }}$, Kathleen R. Simmons ${ }^{\text {a }}$, Lindsey T. Groves ${ }^{b}$, John P. McGeehin ${ }^{\text {c }}$, \\ R. Randall Schumann ${ }^{a}$, Larry D. Agenbroad ${ }^{\mathrm{d}, \dagger}$ \\ a U.S. Geological Survey, MS 980, Box 25046, Federal Center, Denver, CO 80225, USA \\ b Section of Malacology, Natural History Museum of Los Angeles County, 900 Exposition Blvd., Los Angeles, CA 90007, USA \\ c U.S. Geological Survey, MS 926A, National Center, Reston, VA 20192, USA \\ ${ }^{\mathrm{d}}$ Mammoth Site of Hot Springs, South Dakota, Inc., 1800 Highway 18 Truck Route, P.O. Box 692, Hot Springs, SD 57747, USA
}

\section{A R T I C L E I N F O}

\section{Article history:}

Received 1 October 2014

Available online 16 April 2015

Keywords:

Mammoths

California Channel Islands

Marine terraces

Sea-level history

Uranium-series dating

Radiocarbon dating

\begin{abstract}
A B S T R A C T
Fossils of Columbian mammoths (Mammuthus columbi) and pygmy mammoths (Mammuthus exilis) have been reported from Channel Islands National Park, California. Most date to the last glacial period (Marine Isotope Stage [MIS] 2), but a tusk of M. exilis (or immature M. columbi) was found in the lowest marine terrace of Santa Rosa Island. Uranium-series dating of corals yielded ages from $83.8 \pm 0.6$ ka to $78.6 \pm 0.5$ ka, correlating the terrace with MIS 5.1, a time of relatively high sea level. Mammoths likely immigrated to the islands by swimming during the glacial periods MIS 6 ( $\sim 150 \mathrm{ka})$ or MIS 8 ( $250 \mathrm{ka})$, when sea level was low and the island-mainland distance was minimal, as during MIS 2. Earliest mammoth immigration to the islands likely occurred late enough in the Quaternary that uplift of the islands and the mainland decreased the swimming distance to a range that could be accomplished by mammoths. Results challenge the hypothesis that climate change, vegetation change, and decreased land area from sea-level rise were the causes of mammoth extinction at the Pleistocene/Holocene boundary on the Channel Islands. Pre-MIS 2 mammoth populations would have experienced similar or even more dramatic changes at the MIS 6/5.5 transition.
\end{abstract}

Published by Elsevier Inc. on behalf of University of Washington.

\section{Introduction}

Mammoths are one of the most iconic animals of the Pleistocene, both in North America and Eurasia. Interestingly, fossil mammoths and other proboscideans are not limited to just those continents. Fossil proboscideans have been found on islands off North America and Asia, as well as on many islands of the Mediterranean (Fig. 1). On the northern Channel Islands of California (Fig. 2), fossil mammoth remains that have been documented include the Columbian mammoth, Mammuthus columbi and the pygmy mammoth, Mammuthus exilis (Orr, 1968; Johnson, 1978, 1979, 1981; Madden, 1981; Roth, 1993; Agenbroad, 1998, 2001, 2003, 2012; Agenbroad et al., 1999 ,2005). M. columbi immigrated from the mainland to the islands and $M$. exilis evolved from this ancestral stock (Johnson, 1978, 1981; Madden, 1981; Agenbroad, 2001, 2012). Based on fossil evidence for mammoths on the Channel Islands, an absence of other faunal elements, lack of geologic evidence for a former land bridge, and documentation of swimming abilities of modern elephants, Johnson $(1978,1980)$ concluded that mammoths

\footnotetext{
* Corresponding author.

E-mail address: dmuhs@usgs.gov (D.R. Muhs).

$\dagger$ Deceased October 31, 2014.
}

likely reached the California Channel Islands from mainland California by swimming.

If swimming were the means by which mammoths immigrated to the Channel Islands, a question that arises is the timing of this event or events. Johnson (1978) pointed out that the optimal times for immigrations would have been during glacial periods, when eustatically lowered sea levels would have minimized the swimming distance from the mainland to the islands. Radiocarbon ages of either fossil mammoth remains (collagen) or materials associated with such remains (charcoal) fall into two age groups, summarized by Agenbroad (2012). Based on this compilation, and excluding those derived from questionable materials or analyses done in the early period of radiocarbon dating, the most abundant ages for mammoths on the Channel Islands date to the last glacial period ( $\sim 22-12 \mathrm{ka}$, in cal ${ }^{14} \mathrm{C} \mathrm{yr}$ ) or Marine Isotope Stage (MIS) 2. A last-glacial age for mammoths on the Channel Islands supports part of Johnson's (1978) hypothesis, because sea level would have been lower during this time, minimizing the swimming distance from mainland California to the Channel Islands. Johnson (1978) also proposed, however, that mammoth immigration to the Channel Islands need not be limited to the last glacial period, but could occur any time there was a favorable paleogeography, with lowered sea level. Azzaroli (1981) challenged this proposal, asserting that sea levels prior to the last glacial maximum (LGM) were 


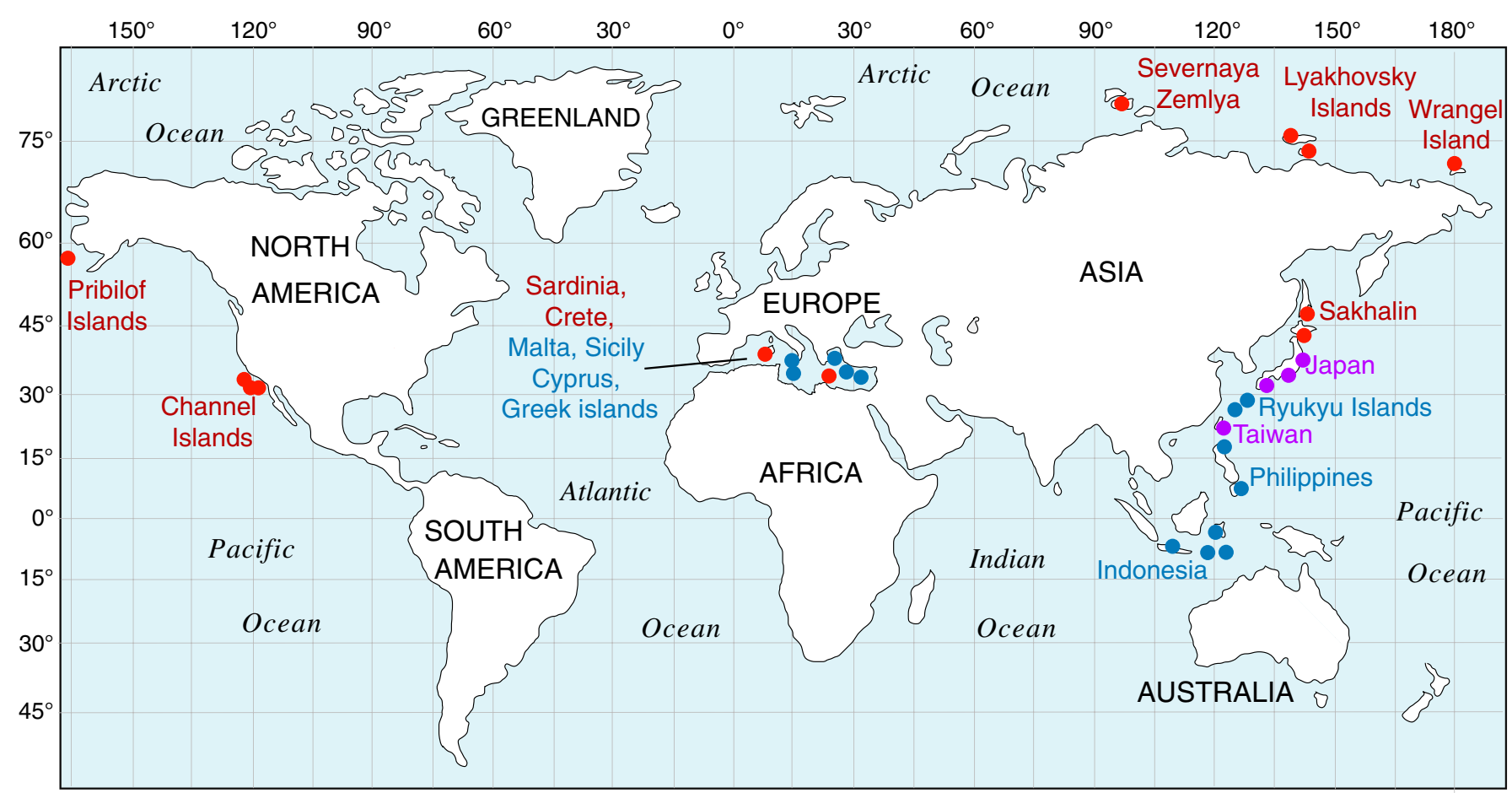

- Mammoths (Mammuthus) Mammoths and other proboscideans

Other proboscideans (Elephas, Palaeoloxodon, Stegodon)

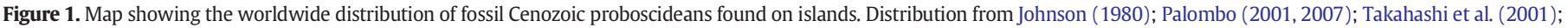

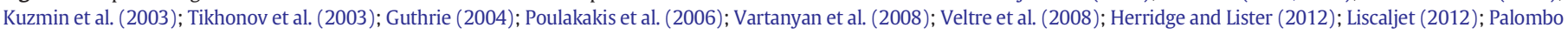
and Rozzi (2013) and sources therein.

no lower than about $-30 \mathrm{~m}$ to $-50 \mathrm{~m}$, relative to present. It is now known, however, that other, pre-LGM glacial periods were characterized by sea levels well below -30 to $-50 \mathrm{~m}$, relative to present, during at least the two glacial periods prior to the LGM (e.g., Lea et al., 2002; Rohling et al., 2009, 2010). Thus, Johnson's (1978) hypothesis of preLGM mammoth immigrations is still a viable one, based on current understanding of sea-level history.

The second group of mammoth ages derive from charcoal fragments associated with mammoth remains from five localities on Santa Rosa Island and have given ages of $>41,000 \mathrm{yr}$ (Agenbroad, 2012). If correct, these ages imply the possibility of mammoth immigrations prior to MIS 2. Further, Orr $(1960,1968)$ reports finding mammoth remains in marine deposits of the lowest emergent terrace on Santa Rosa Island. These observations raise the possibility of considerable antiquity for the presence of mammoths on the Channel Islands. There is evidence that pre-LGM immigrations of proboscideans took place elsewhere, to the Mediterranean islands of Sardinia, Sicily, and Crete, as well as to the island of Flores in Indonesia (Palombo and Rozzi, 2013). Reported here are new marine terrace mapping and geochronology along with two new mammoth finds that provide a test of Johnson's (1978) hypothesis that pre-last-glacial immigrations of mammoths to the Channel Islands might have occurred.

\section{Field and laboratory methods}

\section{Field methods}

Marine terrace deposits and other surficial sediments were mapped on northeastern and northwestern Santa Rosa Island, in part modified from mapping conducted by Weaver et al. (1969) and in somewhat more detail than in Muhs et al. (2014a), both of whom mapped the entire island. Unlike Weaver et al. (1969), Muhs et al. (2014a) and the present work distinguish between low terraces (less than $\sim 30$ m elevation), of late Quaternary age, and high terraces (greater than $\sim 30 \mathrm{~m}$ elevation), hypothesized to be of middle-to-early Quaternary age.
U-series and amino acid geochronology support the correlation of low-elevation terraces to high-sea stands of the last interglacial complex, MIS 5 (Muhs et al., 2014a). Low-elevation terraces are designated as map unit "Qes/Qty" or "Qac/Qty" for Santa Rosa Island. The composite designation indicates that young terrace deposits (Qty) are not exposed at the surface, but are covered by still-younger eolian sand (Qes) or alluvium and/or colluvium (Qac). The spatial extent of these units was determined by initial mapping on National Park Service aerial photographs (2002) and U.S. Geological Survey topographic maps (1943), followed by field examination of terrace geomorphology, exposures in sea cliffs, and outcrops in shore-normal-trending canyons.

No attempt was made to differentiate different ages of middle-toearly Quaternary marine terraces. Older marine terrace deposits (Qto) on Santa Rosa Island are identified by the presence of rounded, waveworn gravel clasts, particularly those with evidence of boring by pholad clams, and/or deposits containing marine invertebrate fossils. Older marine deposits are also typically covered by younger eolian sand (Qes) or alluvium and/or colluvium (Qac). Thus, these older terraces are designated "Qes/Qto" or "Qac/Qto." Possible marine terraces, mapped as unit "Qtpo," are old, high-elevation, low-relief surfaces with gentle seaward slopes, also identifiable in the field and on aerial photographs and topographic maps, that lack definitive marine deposits (rounded, pholad-bored gravels and marine fossils). These surfaces, interpreted as ancient wave-cut platforms, have geomorphic evidence of a marine origin, with possible paleo-sea cliffs and shore-normal surfaces that have concordant elevations with low-relief surfaces bounded by other drainages. Elevations of all localities studied were determined using differential Global Positioning System (GPS) measurements.

Radiocarbon dating of land snails and uranium-series methods of dating marine terrace corals

On the Channel Islands, fossil land snails are commonly found in terrestrial deposits of Quaternary age. Although land snails have, in 

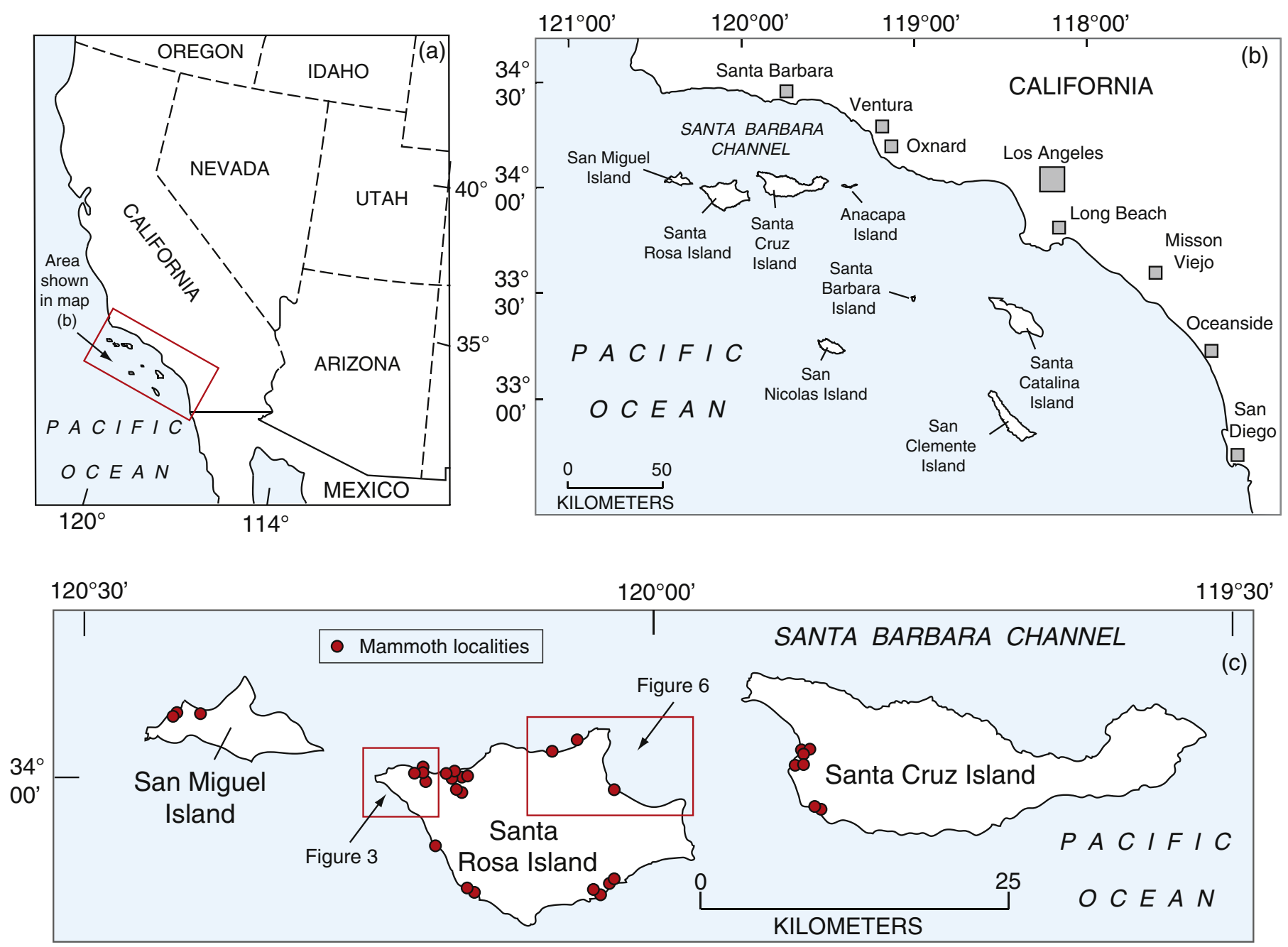

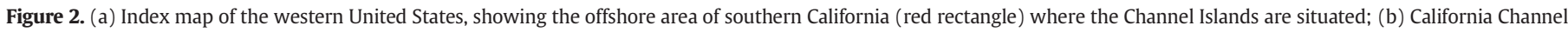

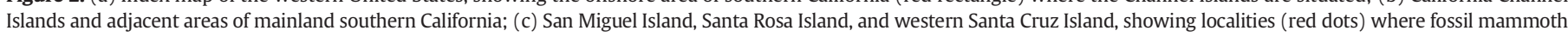
remains have been located. Mammoth locality data from Johnson (1979); Cushing et al. (1984); Agenbroad (1998, 2012); Agenbroad et al. (1999), and the present study.

the past, been regarded as less-than-perfect materials for radiocarbon dating, detailed studies of modern snails show that many species actually show very little age bias, even when they live on a carbonate substrate (Pigati et al., 2010). A later study, comparing radiocarbon ages of land snails in loess to ages of the same loess deposits determined independently, either by radiocarbon ages of wood or luminescence ages of sediment, show that at least some species give reliable ages (Pigati et al., 2013). In the present study, five modern-dead specimens of Helminthoglypta ayresiana (Newcomb, 1861) were collected for an assessment similar to that of the experiments conducted by Pigati et al. (2010). Laboratory procedures follow Pigati et al. (2013) and are summarized briefly here. Shells were separated from the host sediment, placed in a beaker of ASTM Type 1, 18.2 MW (ultrapure) water, and subjected to an ultrasonic bath for a few seconds. The shells were then repeatedly immersed in a second beaker of ultrapure water to remove material adhering to the shell surface or lodged within the shell itself. This process was repeated until the shells were visibly clean. In most cases, shells were selectively dissolved or etched briefly using dilute $\mathrm{HCl}$ to remove secondary carbonate dust from primary shell material. Etched shells were then washed repeatedly in ultrapure water and dried in an oven overnight at $70^{\circ} \mathrm{C}$. Both modern and fossil shells that were free of detritus were converted to $\mathrm{CO}_{2}$ using A.C.S. reagentgrade, $85 \% \mathrm{H}_{3} \mathrm{PO}_{4}$ under vacuum at $50{ }^{\circ} \mathrm{C}$, until the reaction was visibly complete $(\sim 1 \mathrm{~h})$. The resulting $\mathrm{CO}_{2}$ was split into two aliquots. One aliquot was converted to graphite, using an iron catalyst and a standard hydrogen reduction process, and submitted to the Center for Accelerator Mass Spectrometry (CAMS) at Lawrence Livermore National Laboratory. The second aliquot was submitted for $\delta^{13} \mathrm{C}$ analysis in order to correct the measured ${ }^{14} \mathrm{C}$ activity of the shell carbonate for isotopic fractionation.

For marine terrace deposits, fossil corals are used for uranium-series dating. All corals, whether colonial or solitary, take up U in isotopic equilibrium with sea water, contain little or no Th, and, under favorable circumstances, behave as closed systems with respect to ${ }^{238} \mathrm{U}$ and its longlived daughter products, ${ }^{234} \mathrm{U}$ and ${ }^{230} \mathrm{Th}$, after death and emergence. The solitary coral Balanophyllia elegans Verrill, 1864 presently lives along the Pacific Coast of North America from southeastern Alaska to central Baja California, Mexico and is the most common coral occurring as a fossil in marine terrace deposits of this region. It is potentially suitable for U-series dating because living specimens incorporate measurable $U$ in isotopic equilibrium with seawater (Muhs et al., 2002a, 2006).

Fossil corals collected from marine terrace deposits on Santa Rosa Island were cleaned mechanically, washed in distilled water, and X-rayed for aragonite purity. All samples but one are 100\% aragonite; a single sample is $99 \%$ aragonite. Analyses were made of individual coral specimens of B. elegans. Sample preparation follows methods outlined by Ludwig et al. (1992), summarized briefly here. Cleaned corals were dissolved in $\mathrm{HNO}_{3}$, spiked with ${ }^{229} \mathrm{Th},{ }^{233} \mathrm{U}$, and ${ }^{236} \mathrm{U}$ (calibrated 
primarily with a secular equilibrium standard; see Ludwig et al., 1992) and purified with ion exchange methods. Purified $U$ and Th were loaded with colloidal graphite on separate Re filaments. Isotopic abundances were determined by thermal ionization mass spectrometry (TIMS). Ages were calculated using a half-life for ${ }^{230} \mathrm{Th}$ of $75,584 \mathrm{yr}$ and a halflife for ${ }^{234} \mathrm{U}$ of $245,620 \mathrm{yr}$ (Cheng et al., 2013).

\section{Results: marine terrace mapping, fossils, and geochronology}

Marine terraces on northwestern Santa Rosa Island

Orr $(1960,1968)$ conducted the first detailed studies of marine terraces on Santa Rosa Island. Much of Orr's $(1960,1968)$ marine terrace work in the northwestern part of Santa Rosa Island was based on field studies conducted between Sandy Point and Brockway Point, in Cañada Garañon and Arlington Canyon (Fig. 3). Exposures that were examined along the outer part of Cañada Garañon (localities SRI-5D, E, G, H, J in Fig. 3) in the present study display two late Quaternary marine terraces that are believed to be the equivalent of Orr's $(1960,1968) \sim 7 \mathrm{~m}$ and $\sim 23 \mathrm{~m}$ terraces. Orr $(1960,1968)$ also proposed formal names for the sediments overlying the $\sim 7 \mathrm{~m}$ and $\sim 23 \mathrm{~m}$ terraces, the Garañon and Fox members of the Santa Rosa Island Formation, respectively. The sediments of these formations include both marine deposits associated with the wave-cut platforms and younger, overlying terrestrial sediments that include alluvium, colluvium, and eolian sand (Fig. 4). In Cañada Garañon, the shoreline angle elevation is $7.4 \mathrm{~m}$ for the lower terrace and $\sim 24 \mathrm{~m}$ for the higher terrace (Fig. 5). Hereafter, these are referred to as the "1st" $(\sim 7 \mathrm{~m})$ and "2nd" ( $24 \mathrm{~m})$ terraces. Marine deposits on both terraces are $\sim 0.5-1.0 \mathrm{~m}$ thick. About $16-17 \mathrm{~m}$ of alluvium overlie marine deposits of the 1st terrace and 4-6 $\mathrm{m}$ of alluvium and eolian sand overlie marine deposits of the 2nd terrace (Figs. 4 and 5). The 1st terrace can be traced continuously west to Sandy Point (Figs. 3, 5) in sea cliff exposures; the 2nd terrace is also likely present along much of this reach of coastline, but is obscured by overlying deposits of eolian sand.

Both the 1st and 2nd terraces on the northwest coast of Santa Rosa Island are richly fossiliferous. Deposits of the 2nd terrace, where it is exposed in Cañada Garañon (fossil localities SRI-5D, 5E, and 5J), and in canyons to the east of it (SRI-5F in Fig. 3) contain a typical rocky-shore assemblage, including Epilucina californica (Conrad, 1837), Cumingia californica Conrad, 1837, Glans sp., Callianax biplicata (Sowerby, 1825), Conus californicus Reeve, 1844, Fissurella volcano Reeve, 1849, Chlorostoma sp., Haliotis sp. or spp., Acmaea spp., and other mollusks, as well as numerous specimens of $B$. elegans. The 1st terrace in the same area (SRI-5) has a somewhat less diverse rocky-shore assemblage, consisting of E. californica, Glans carpenteri (Lamy, 1922), F. volcano, Haliotis sp. or spp., Acmaea spp., and rare B. elegans. Orr $(1960,1968)$ also reported many of the same fossils in deposits of both the 1st and 2nd terraces in this area. Fossils in deposits of the 1st terrace a short distance northeast of Sandy Point (SRI-27 in Figs. 3 and 5) are more abundant than those at SRI-5, containing many of the same taxa, but also hosting Mytilus californianus Conrad, 1837, Chlorostoma sp., Serpulorbis squamigeris (Carpenter, 1857) and abundant corals (B. elegans). Based on amino acid geochronology of Chlorostoma fossils (1st and 2nd terraces) and a single U-series age on a coral (2nd terrace only), Muhs et al. (2014a) correlated the 1st and 2nd terraces on this part of Santa Rosa Island to the $\sim 80 \mathrm{ka}$ (MIS 5.1) and $\sim 120 \mathrm{ka}$ (MIS 5.5) high-sea stands, respectively.

\section{$120^{\circ} 10^{\prime} 00^{\prime \prime}$}

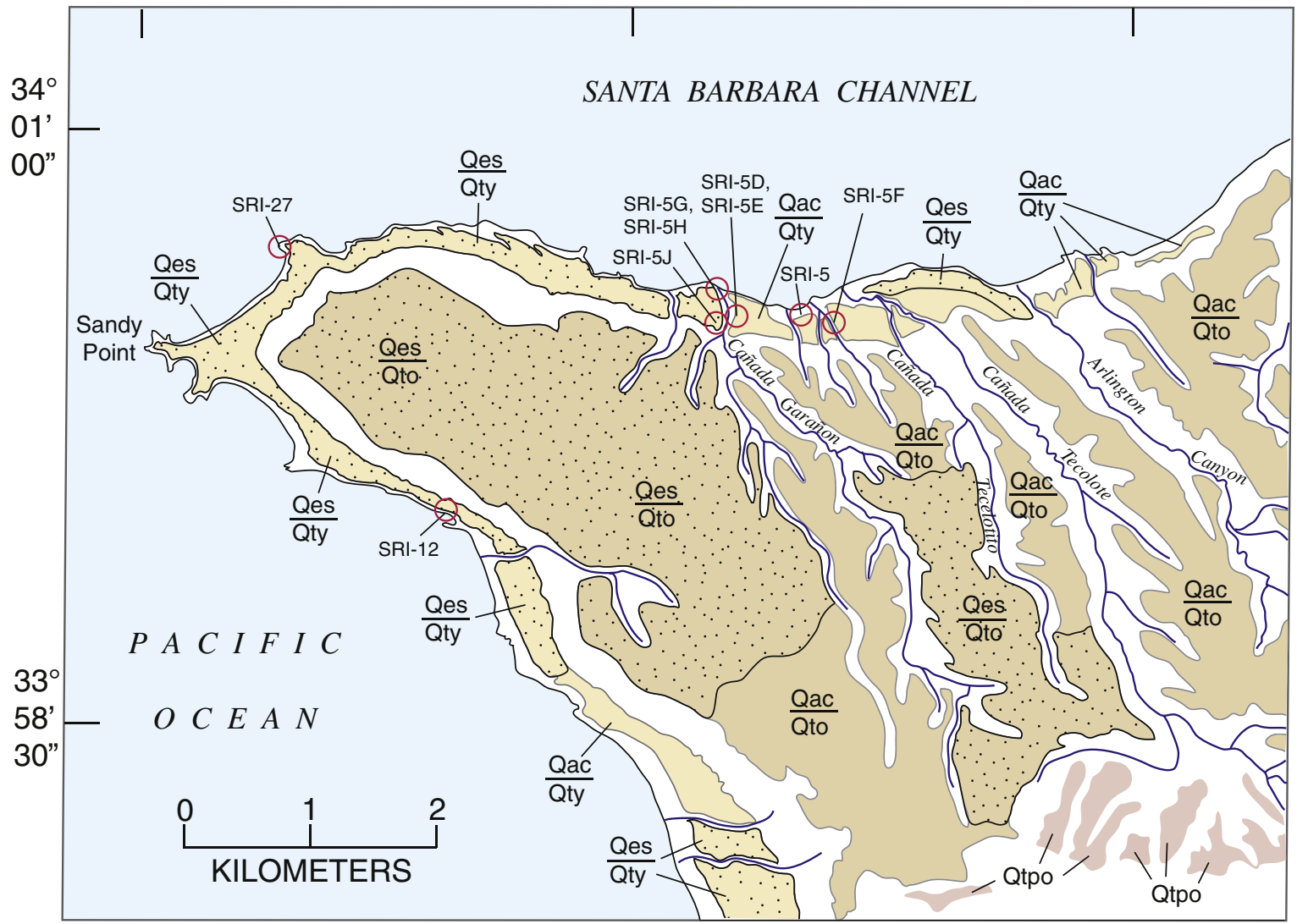

EXPLANATION

Qac

Qty

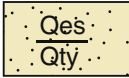

Alluvium/colluvium Qac) or eolian sand (Qes) over younger marine terrace deposits (Qty)

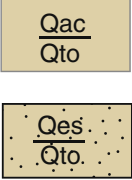

Alluvium/colluvium (Qac) or eolian sand (Qes) over older marine terrace deposits (Qto)

Qtpo

Marine terrace platforms (?), older

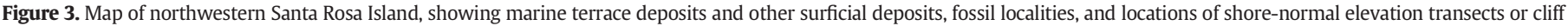

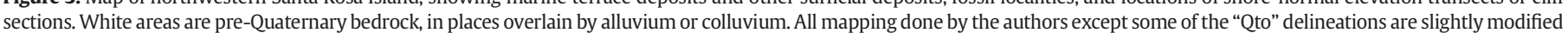
from Weaver et al. (1969). Note that unit designated as "Otpo," possible marine terrace platforms, may or may not have overlying marine and/or terrestrial deposits. 


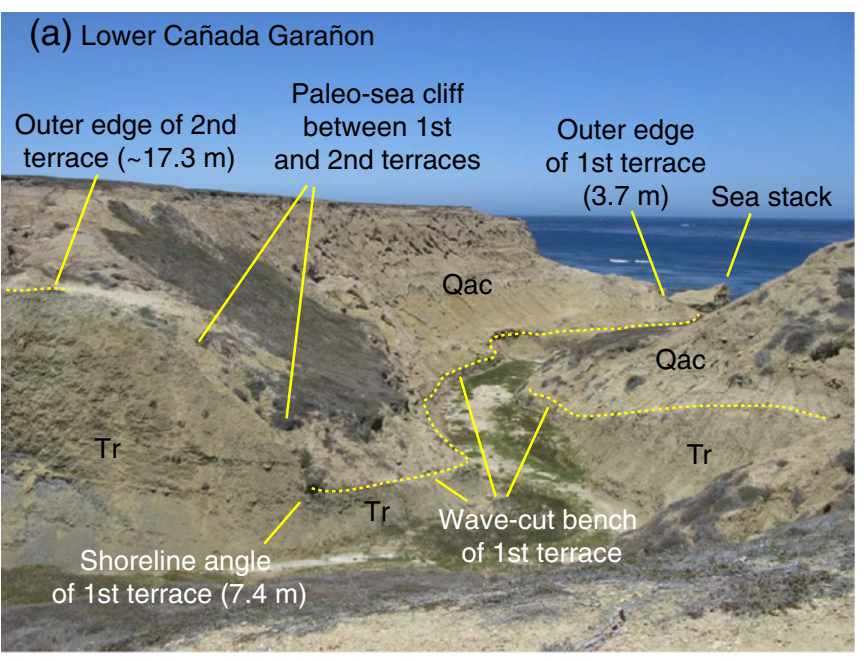

(b) Sea stack location

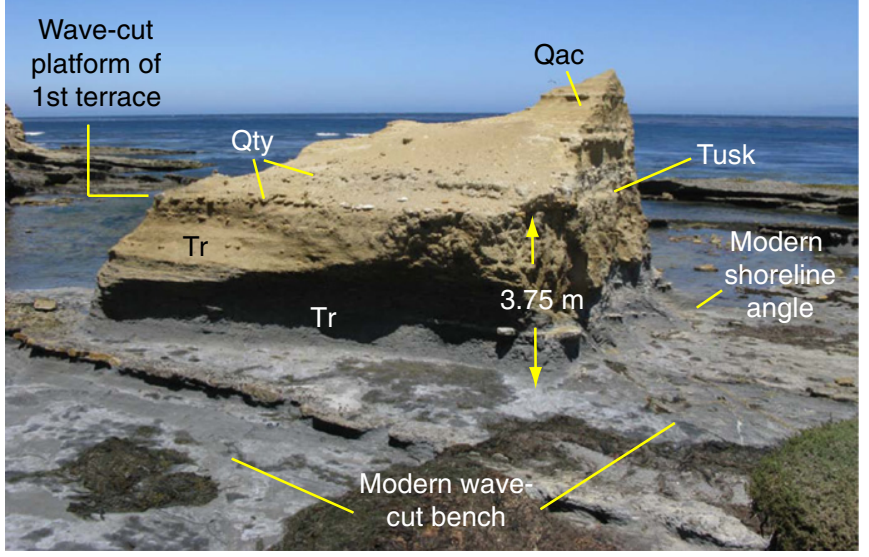

Figure 4. (a) Photograph of lower Cañada Garañon, Santa Rosa Island, showing marine terraces and overlying deposits and location of sea stack where mammoth tusk was found. (b) Photograph of sea stack illustrated in (a) showing geomorphic features and geologic units. Qal, alluvium and/or colluvium; Qty, marine terrace deposits, younger; Tr, Rincon Formation.

\section{Marine terraces on northeastern Santa Rosa Island}

On the northeastern coast of Santa Rosa Island (Fig. 6), overlying eolian, alluvial and colluvial deposits obscure much of the late Quaternary marine terrace geomorphology. Based on field studies conducted here, only a single late Quaternary marine terrace can be identified with any degree of confidence in most outcrops (Muhs et al., 2014a). Whether this feature corresponds to the 1st terrace or 2nd terrace of northwestern Santa Rosa Island cannot be determined by field evidence alone. Most terrace deposits in the Bechers Bay area of northeastern Santa Rosa Island are not fossiliferous and corals suitable for uraniumseries dating were found only at a single locality, SRI-1 (Fig. 6). At SRI1 , the terrace shoreline angle is not exposed, but the wave-cut platform has an outer edge elevation of $5 \mathrm{~m}$ to $6 \mathrm{~m}$ and can be traced around Carrington Point. Marine deposits at SRI- 1 are $\sim 1 \mathrm{~m}$ or more thick and a paleosol has developed in the upper part of these sediments. This paleosol is overlain by $14.4 \mathrm{~m}$ of mostly eolian sand with occasional colluvial gravel. A typical rocky-shore assemblage was found in the marine deposits at SRI-1 including, among other taxa, E. californica, G. carpenteri, M. californianus, C. biplicata, Chlorostoma sp., C. californicus, S. squamigeris, Haliotis rufescens Swainson, 1822, Lottia scabra (Gould, 1846), and Hipponix tumens Carpenter, 1864, as well as three specimens of B. elegans. Amino acid geochronology of Chlorostoma fossils from SRI-
1 led Muhs et al. (2014a) to correlate this terrace with either the $\sim 120$ ka (MIS 5.5) or $\sim 100$ ka (MIS 5.3) high-sea stands.

West of Carrington Point (Fig. 6), discontinuous tracts of marine terrace platforms and overlying marine deposits can be mapped, but again shoreline angles are not exposed and only one terrace can be identified with certainty. In most places, this terrace has an outer edge elevation of $\sim 9 \mathrm{~m}$ to $\sim 11 \mathrm{~m}$ above sea level. Because only one low-elevation terrace can be found in this area, a working hypothesis is that the terrace platform south of Carrington Point (including the one exposed at SRI-1) is equivalent to that found west of Carrington Point. Differences in elevation of outer platform edges ( 5-6 m south of Carrington Point vs. 9$11 \mathrm{~m}$ west of Carrington Point) could be due to local displacement by faults that have been mapped in this area (Weaver et al., 1969), but this requires further study.

\section{Mammoth remains in terrestrial and marine terrace deposits}

West of Carrington Point and east of the mouth of Lobo Canyon, at locality SRI-1F (Fig. 6), a marine terrace platform cut on Tertiary Bechers Bay Formation bedrock is exposed (Fig. 7a; coordinates are N34 $01^{\prime}$ $\left.11.5^{\prime \prime} ; \mathrm{W} 120^{\circ} 05^{\prime} 28.7^{\prime \prime}\right)$. Patchy and weakly cemented marine terrace sands and gravels that are sparsely fossiliferous (E. californica and various limpets) rest on the wave-cut platform, which has an outer edge elevation of $9.4 \mathrm{~m}$. Overlying the marine terrace deposits are two units of eolian sand and colluvium, Qes/Qc1 and Qes/Qc2, shown in Figures 7a and b. In the lower unit (Qes/Qc1), a mammoth tusk was found, $\sim 0.5 \mathrm{~m}$ above the top of the marine terrace deposits. A possible mammoth tibia was also found in this unit, but higher in the section (Fig. 7b). Whether the possible tibia is related to the tusk is not known.

Tusk measurements of $M$. exilis and $M$. columbi given by Agenbroad (2003) permit speculation about which species of mammoth is found in the marine terrace deposits at SRI-1F. For M. columbi, proximal tusk diameters have an overall range of $\sim 10-23 \mathrm{~cm}$ and a mean value of $\sim 18 \mathrm{~cm}$, whereas for $M$. exilis this range is $\sim 3-8 \mathrm{~cm}$, with a mean value of $5.4 \mathrm{~cm}$. The tusk at SRI-1F has a proximal diameter of $8 \mathrm{~cm}$ and it is inferred that this could be a specimen of M. exilis, a female M. columbi, or an immature M. columbi of either gender.

The age of the tusk at SRI-1F can be constrained by both uraniumseries and radiocarbon dating. The tusk is hosted by an eolian/colluvial unit that is stratigraphically younger than the marine terrace deposits. Thus, we use uranium-series ages of fossil corals collected from SRI-1, assumed to be the same age as the terrace at SRI-1F, as a maximumlimiting age for the tusk. Fossil land snails were found below and above the tusk within the Qes/Qc1 unit, and all are identified as $H$. ayresiana, which lives today on the northern Channel Islands. These snails were collected for radiocarbon dating.

A more definitive age is possible for another mammoth tusk, found on the northwestern part of Santa Rosa Island. As alluded to earlier, Orr $(1960,1968)$ noted the presence of mammoth (Mammuthus sp.) fossils in what he referred to as the Garañon Member of his Santa Rosa Island Formation, on the northwestern coast of the island. In the terminology used in the present paper, these are referred to simply as marine deposits of the 1st terrace. At Cañada Garañon, exposures of this terrace were examined carefully and a well-preserved mammoth tusk, hosted by marine deposits, was discovered in a sea stack, just offshore from the main outcrop of the 1 st terrace at the mouth of the canyon (locality SRI-5G; Figs. 3-5). The stratigraphy of the 1st terrace that is exposed on the sea cliff at the mouth of Cañada Garañon is also preserved on the stack, with the wave-cut bench at an elevation of $3.75 \mathrm{~m}$ above sea level, identical to that of the wave-cut bench exposed on the sea cliff at the mouth of the canyon (Figs. 4, 5). The tusk was found resting directly on the wave-cut platform (Figs. 4, 8) on its seaward end and $\sim 2 \mathrm{~cm}$ above it on its shoreward end. Although the sediments hosting the tusk are poorly sorted and contain some angular clasts, similar to the overlying $2.0-2.5 \mathrm{~m}$ of alluvium, clasts with pholad borings were also found, and marine fossils were observed as much as 
1st terrace ( 80 ka)
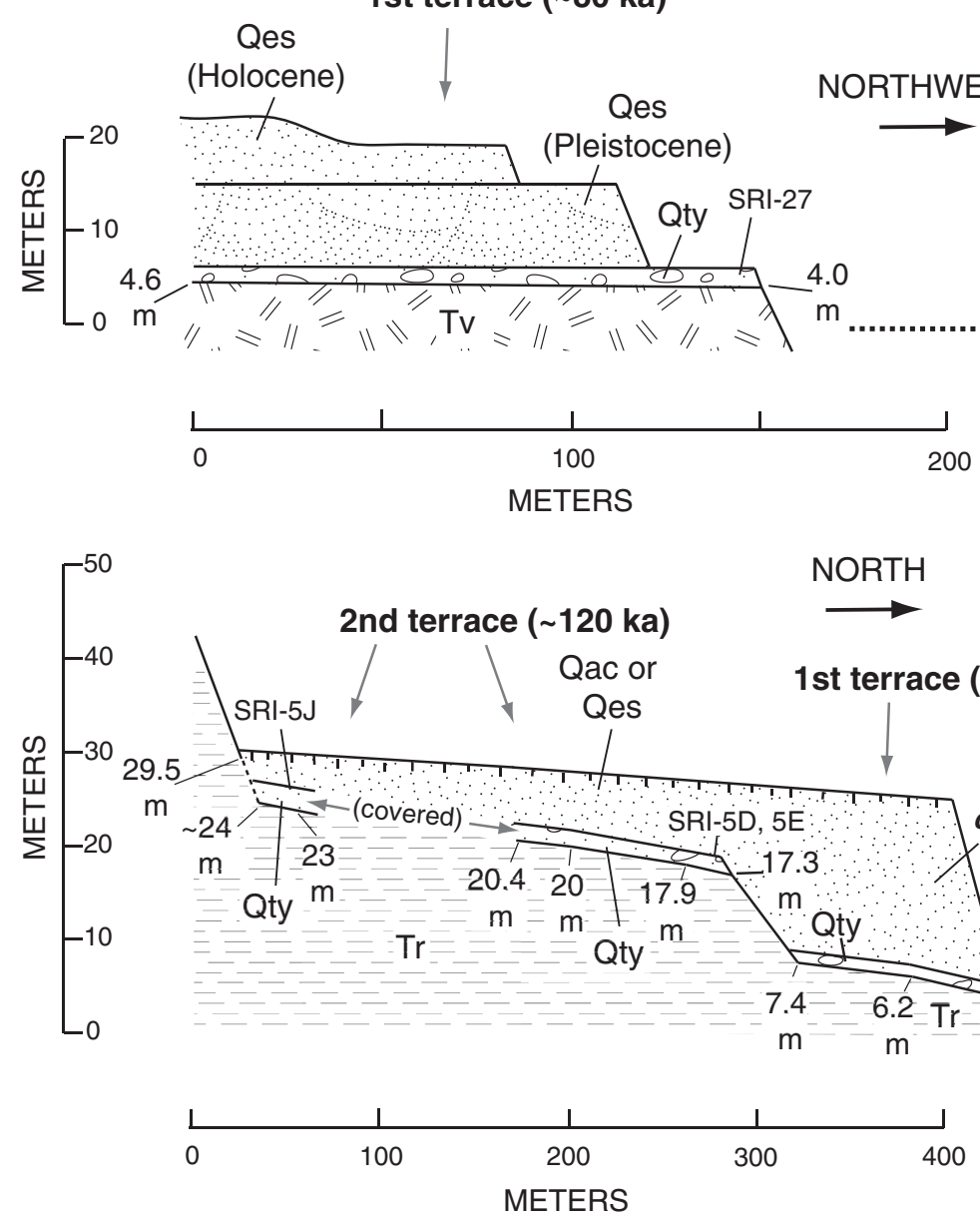

METERS (c) Between

Cañada

Garañon and Cañada Tecelotito
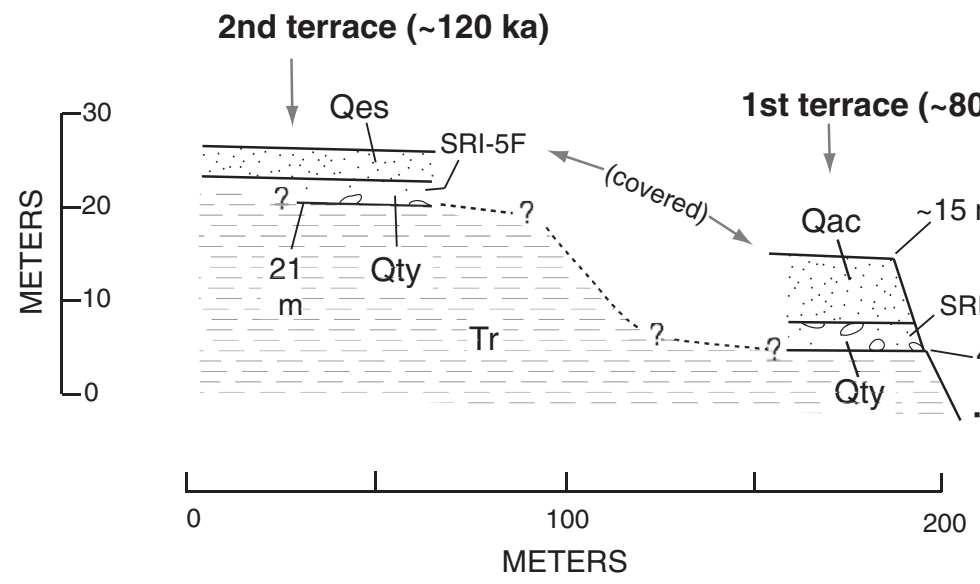

(b) Lower

Cañada

Garañon

(a) Northeast of Sandy Point

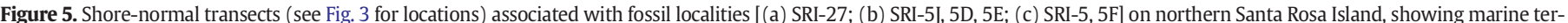

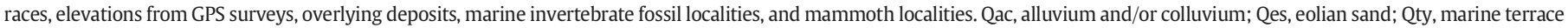
deposits, younger; Tr, Rincon Formation; Tv, tertiary volcanic rocks. Profile data slightly modified from Muhs et al. (2014a).

$40 \mathrm{~cm}$ above the tusk. Marine fossils recovered include the gastropods F. volcano, L. scabra, and Littorina scutulata (Gould, 1849), all of which were also reported by $\operatorname{Orr}(1960,1968)$ from marine deposits of the 1 st terrace in this area. The deposit also contains marine mammal remains. Initial examination of these remains suggested sea otter or sea lion bone fragments (Howell Thomas, Natural History Museum of Los Angeles County, personal communication, March, 2014). Later, James Dines (also of the Natural History Museum of Los Angeles County, personal communication, January 2015) examined these materials and made comparisons to modern specimens housed in the Natural History Museum of Los Angeles County. He identified the remains as the sea otter Enhydra lutris (Linnaeus, 1758). Reworked Miocene fossils from the Tertiary Rincon Formation, including Turritella temblorensis Wiedey, 1928, were also found in the host sediments, as also noted by Orr (1968). Based on all these observations, the host sediments for the tusk are interpreted to be marine deposits. It is inferred that the tusk was eroded from land and then transported to the modern surf zone at the time the wave-cut bench of the 1 st terrace was forming. 


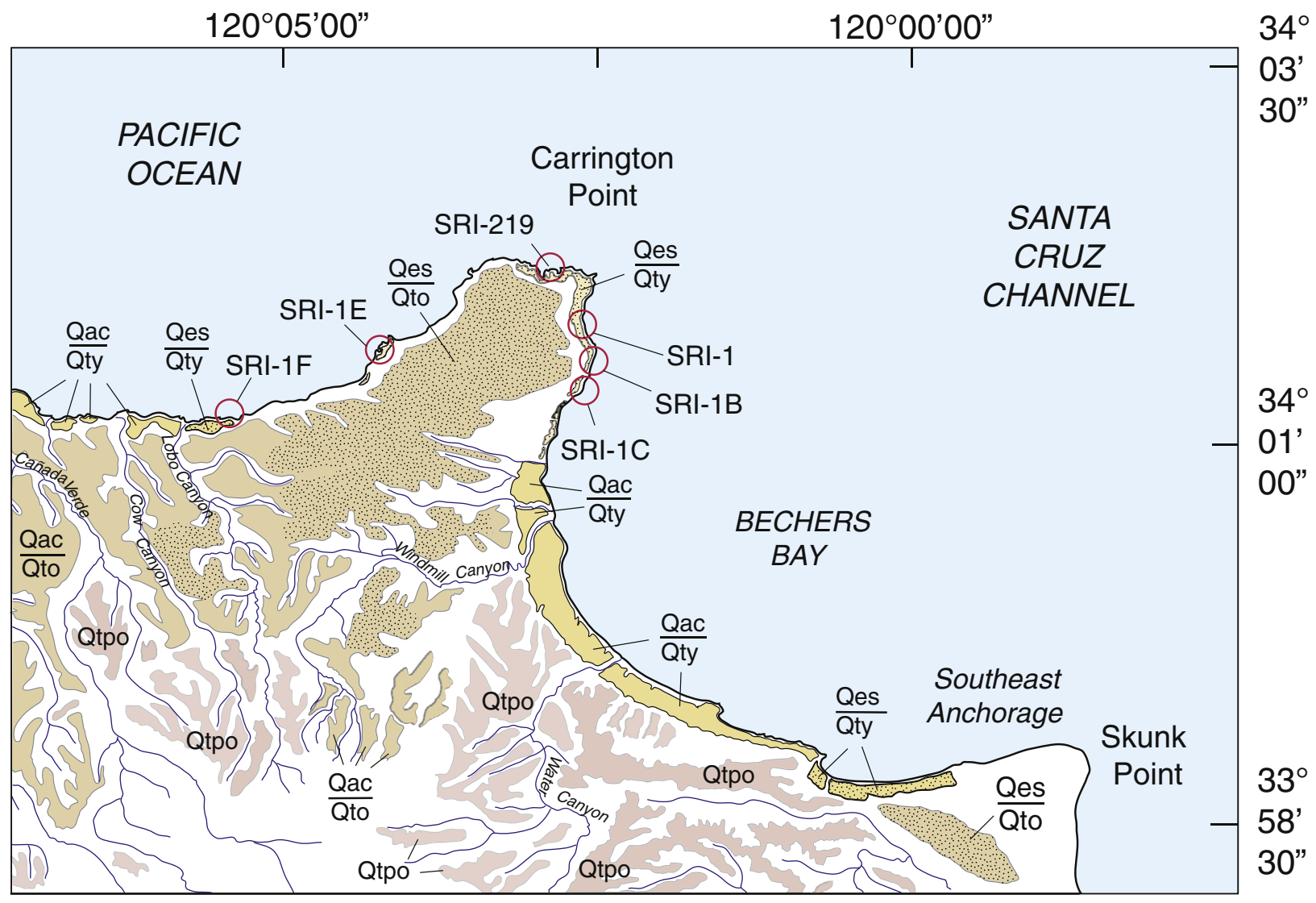

\begin{tabular}{ccc}
$\frac{\text { Qac }}{\text { Qty }}$ & $\begin{array}{c}\text { Alluvium/colluvium } \\
\text { (Qac) or eolian sand } \\
\text { (Qes) over younger }\end{array}$ & $\frac{\text { Qac }}{\text { Qto }}$ \\
Qes & $\begin{array}{c}\text { marine terrace } \\
\text { deposits (Qty) }\end{array}$ & Qes \\
\hline Qty & Qto
\end{tabular}

Alluvium/colluvium
(Qac) or eolian sand
(Qes) over older
marine terrace
deposits (Qto)

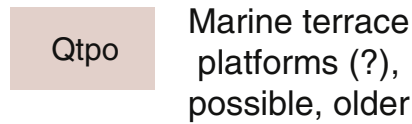

SRI-1F

\section{Marine terrace \\ fossil locality}

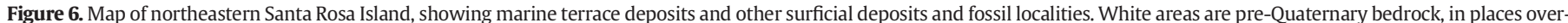

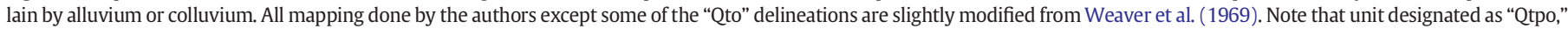
possible marine terrace platforms, may or may not have overlying marine and/or terrestrial deposits.

Unfortunately, within the marine deposits where the tusk was found, no corals for U-series dating were found. Nevertheless, the terrace can be easily traced in sea cliff exposures from Cañada Garañon westward to Sandy Point (Fig. 3). At locality SRI-27, $3 \mathrm{~km}$ to the west of the tusk locality, abundant fossil corals were found in deposits of the 1st terrace (Fig. 5), as noted above, and the age of the terrace can be derived from U-series dating of these corals.

The better exposure of the tusk at SRI-5G at Cañada Garañon permits a more definitive identification than for the tusk at SRI-1F east of Lobo Canyon. The tip-to-base chord length for M. columbi reported by Agenbroad (2003) has an overall range of 95-177 cm and a mean value of $\sim 148 \mathrm{~cm}$, whereas $M$. exilis from the Channel Islands has an overall range of $7.5-72 \mathrm{~cm}$ and a mean value of $\sim 38 \mathrm{~cm}$ for this dimension. For M. columbi, the proximal tusk diameter has an overall range of $\sim 10-23 \mathrm{~cm}$ and a mean value of $\sim 18 \mathrm{~cm}$, whereas for $M$. exilis this range is $\sim 3-8 \mathrm{~cm}$, with a mean value of $5.4 \mathrm{~cm}$. Because the tusk found in the present study has a tip-to-base chord length of $62 \mathrm{~cm}$ and a proximal tusk diameter of $8 \mathrm{~cm}$ (Fig. 8), it is concluded that the specimen from
SRI-5G is likely a pygmy mammoth, $M$. exilis, although we cannot exclude the possibility that it is a female $M$. columbi or an immature M. columbi of either gender.

Elsewhere in the vicinity of the pygmy mammoth specimen at SRI$5 \mathrm{G}$, but stratigraphically above it, another tusk was found, as float $\left(\mathrm{N} 34^{\circ} 00.356^{\prime}, \mathrm{W} 120^{\circ} 12.187^{\prime}\right)$. This tusk was apparently eroded from the alluvial deposits that overlie the marine facies of the 1st marine terrace (Fig. 9). At present, it is situated $\sim 2 \mathrm{~m}$ above the top of the marine terrace deposits. Orr (1968) also noted the presence of mammoth remains in these deposits (what he referred to as the terrestrial deposits of the Garañon member of the Santa Rosa Island Formation). The specimen found in the present study has a length of at least $40 \mathrm{~cm}$ (a minimum figure, as the tusk is clearly incomplete) and a proximal tusk diameter of at least $10.5 \mathrm{~cm}$. Based on the criteria described above, this specimen is tentatively identified as M. columbi. Because the tusk is not in place, all that can be ascertained is that it is younger than the marine terrace deposits where the possible M. exilis tusk was found at Cañada Garañon. 


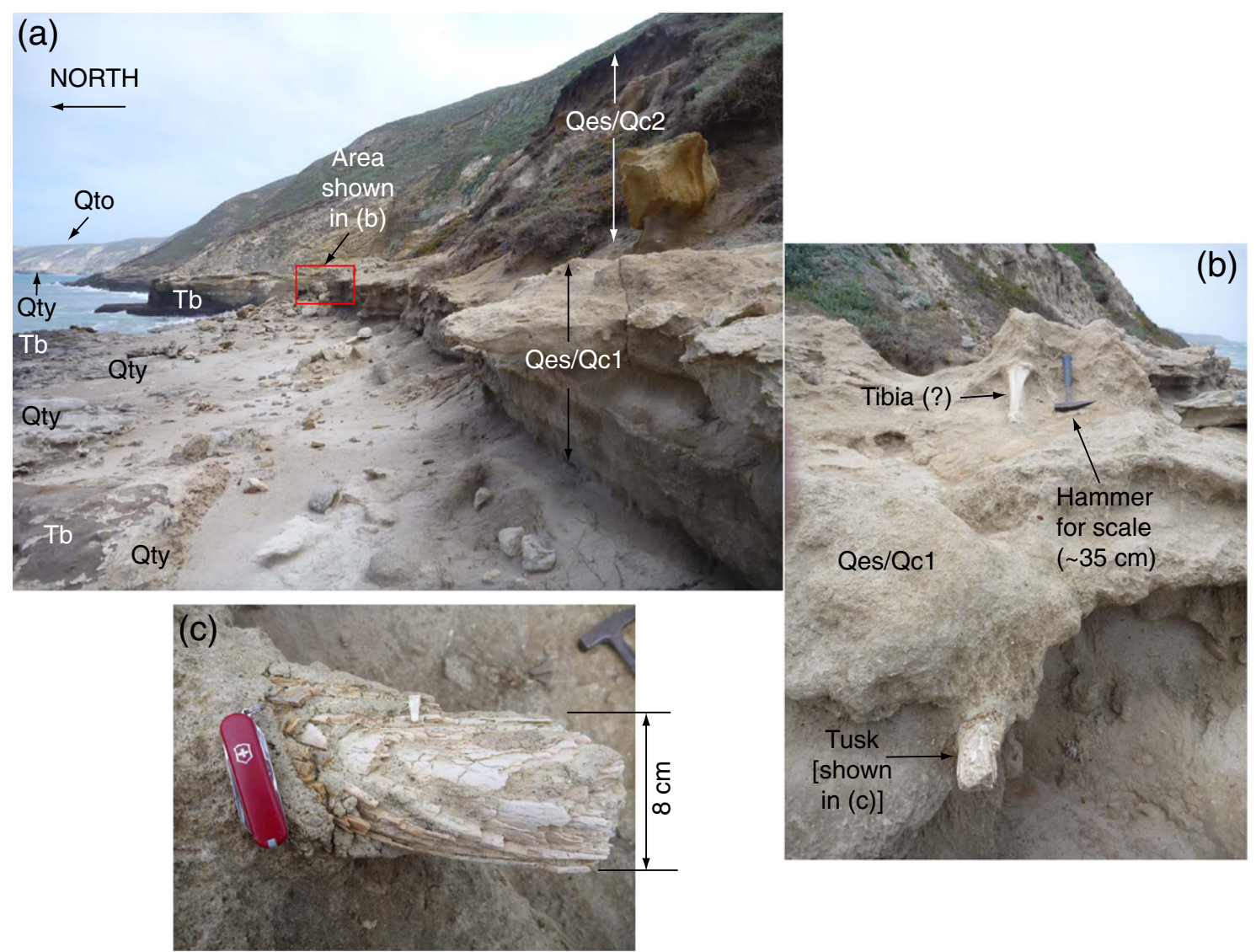

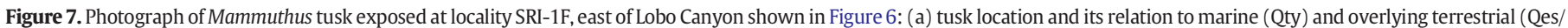

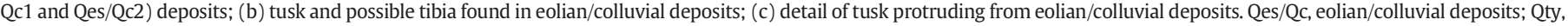
marine terrace deposits, younger; Tb, Bechers Bay Formation (informal name).

Radiocarbon dating of terrestrial snails and uranium-series dating of marine terrace corals

Fossil land snails found in the eolian/colluvial deposits (Qes/Qc1) that host the M. exilis tusk at SRI-1F, east of Lobo Canyon, potentially provide valuable age information. Nevertheless, in order to test whether $H$. ayresiana snails from the Channel Islands can be regarded as a species with minimal age bias, it is necessary to determine the apparent radiocarbon ages of modern snails. We collected five specimens of modern, dead (but still retaining shell patterning and color) $H$. ayresiana from carbonate substrates (Quaternary eolianite or marine deposits) on nearby San Miguel Island. The choice of carbonate substrates was deliberate, in order to capture a worst-case scenario for the possible "limestone effect" in this species, following the approach of Pigati et al. (2010). Results show that these snails are likely biased by $\sim 500 \mathrm{yr}$ to perhaps as much as $\sim 1000 \mathrm{yr}$ (Table 1 ). This range of values is similar to the range of maximum limestone effect bias exhibited by a couple dozen species of land snails studied by Pigati et al. (2010). Thus, any ages derived from fossil H. ayresiana should be regarded as $500-1000 \mathrm{yr}$ too old.

With knowledge of the probable age bias, fossil land snails constrain the age of the tusk found east of Lobo Canyon. Fossil snails SRI-1F-75 and SRI-1F-70 were collected $75 \mathrm{~cm}$ and $70 \mathrm{~cm}$, respectively, above the top of the marine terrace deposits that underlie the tusk-bearing unit, Qes/Qc1. Because the tusk was found at $50 \mathrm{~cm}$ above the marine terrace deposits, these snails are therefore only 25 and $20 \mathrm{~cm}$ above the tusk. Both snails yielded apparent radiocarbon ages of $~ 41,000$ $42,000{ }^{14} \mathrm{Cyr}$ BP (Table 1 ). About $40 \mathrm{~m}$ west of where the tusk was

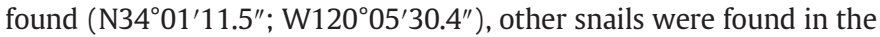
same Qes/Qc1 unit, but somewhat higher stratigraphically, at $100 \mathrm{~cm}, 127 \mathrm{~cm}$, and $143 \mathrm{~cm}$ above the top of the marine terrace deposits (SRI-1 F-100,127, and 143, respectively). These snails gave apparent radiocarbon ages of $\sim 41,000$ to $\sim 46,000{ }^{14} \mathrm{Cyr} \mathrm{BP}$, in broad agreement with the snails somewhat lower in the section (Table 1 ). As pointed out by Pigati et al. (2007), for materials near or beyond the limit of radiocarbon dating, only very small amounts of modern carbon are required to contaminate an infinitely old sample in such a way as to generate an apparently finite radiocarbon age. Thus, we regard all five radiocarbon ages on these snails as minimumlimiting ages for the tusk.

It is possible to estimate a maximum-limiting age for the tusk east of Lobo Canyon from the age of the marine terrace deposits that underlie the tusk-bearing unit. Although no corals were found in the marine terrace deposits underlying the tusk at locality SRI-1F, corals (B. elegans) were collected from the lowest emergent terrace on the other side of Carrington Point, at locality SRI-1 (Fig. 6). It is assumed, for the purpose of the present study, that because both the terrace fragments at SRI-1F and SRI-1 are the lowest emergent terraces and have similar outer edge elevations ( +9.4 and $+5.3 \mathrm{~m}$, respectively) that they are correlative. This assumption requires more testing, but is presented here as a working hypothesis. From locality SRI-1, all three corals are 100\% aragonite, indicating no diagenetic alteration to calcite, and all have $\mathrm{U}$ contents similar to those of modern and fossil B. elegans reported elsewhere in California and Baja California (Muhs et al., 2002a, 2006, 2012), indicating no evidence of $U$ loss (Table 2). Concentrations of ${ }^{232} \mathrm{Th}$ are low and ${ }^{230} \mathrm{Th} /{ }^{232} \mathrm{Th}$ values are high, indicating no inherited 

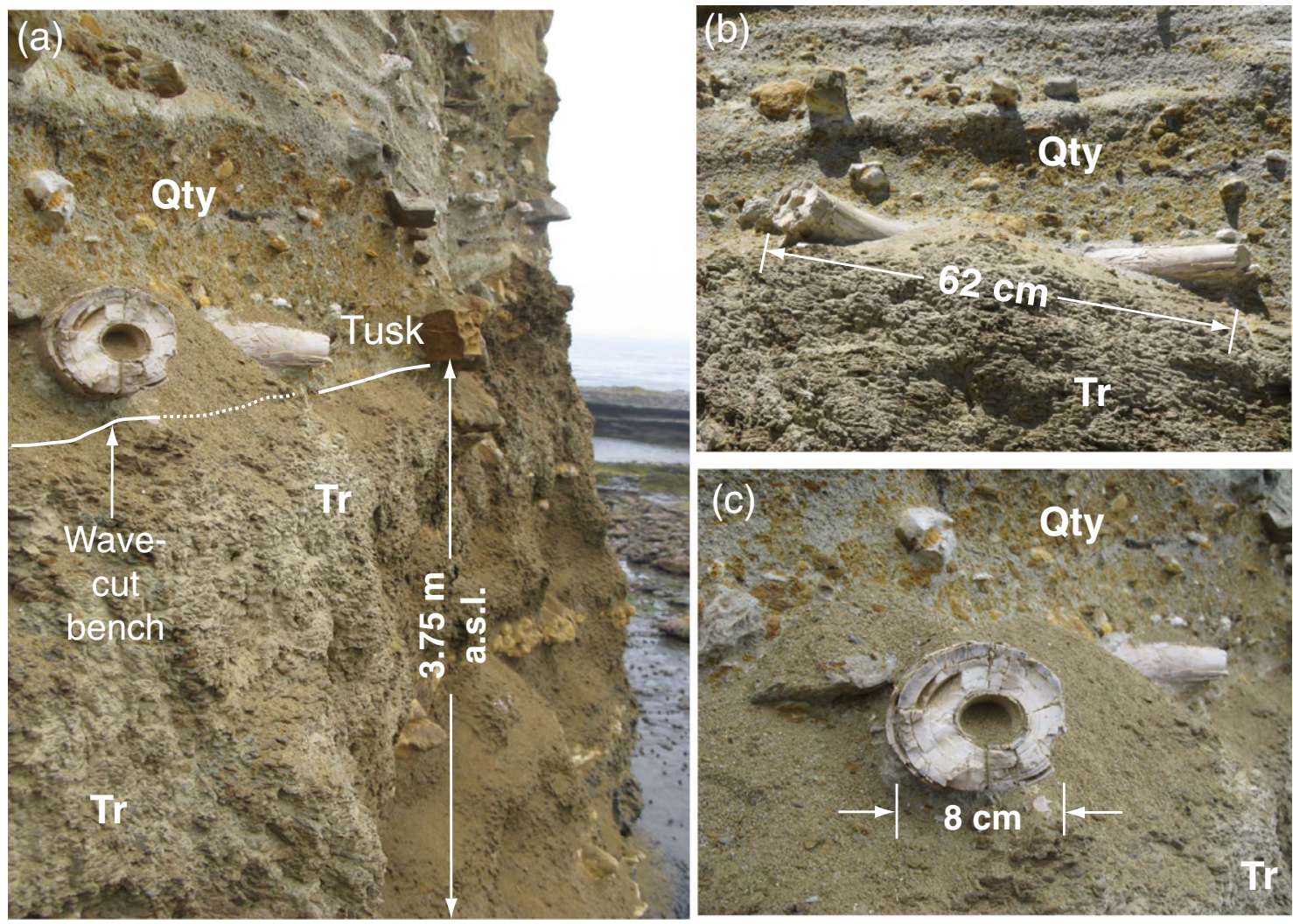

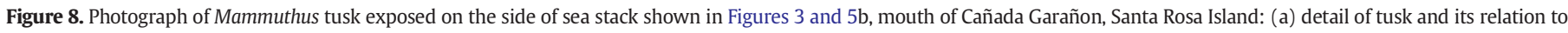
wave-cut bench and host marine terrace deposits; (b) horizontal dimension of tusk; (c) diameter of inner part of tusk. Qty, marine terrace deposits, younger; Tr, Rincon Formation.

${ }^{230}$ Th derived from detrital silicate minerals. A duplicate analysis of SRI1-B shows good agreement, within the limits of analytical uncertainty. Ages of the three corals range from $113.1 \pm 0.6 \mathrm{ka}$ to $110.5 \pm 0.6 \mathrm{ka}$. All three corals have back-calculated initial ${ }^{234} \mathrm{U} /{ }^{238} \mathrm{U}$ values that are somewhat higher than that of modern seawater, which ranges from $\sim 1.141$ to $\sim 1.155$ and averages $\sim 1.149$ (Delanghe et al., 2002). When viewed on an isotopic evolution curve, such corals plot somewhat higher on the vertical axis than the idealized evolutionary pathway that would be followed by corals that exhibited strictly closed-system conditions with respect to U-series nuclides (Fig. 10). Based on the model presented by Gallup et al. (1994), the ages could be biased old by perhaps as much as $\sim 2-3 \mathrm{ka}$. Thus, when compared to $\sim 120$ ka corals (marine isotope stage, or MIS 5.5, following the terminology of Martinson et al., 1987) from Terrace 2a on San Nicolas Island (Muhs et al., 2006, 2012) or the Sea Cave terrace of Punta Banda, Baja California, Mexico (Muhs et al., 2002a), the corals from SRI-1 appear to be slightly younger. It is possible that the SRI-1F corals could correlate with the very youngest part of MIS 5.5, or possibly with MIS 5.3 ( $100 \mathrm{ka})$, in agreement with the amino acid age estimates for mollusks from this locality (Muhs et al., 2014a). It is unlikely that the corals are as young as $\sim 80$ ka, or MIS 5.1, however (Fig. 10). Therefore, based on the stratigraphy and combined radiocarbon and U-series dating, the age of the tusk is more than $\sim 46-40 \mathrm{ka}$ but less than $\sim 120 \mathrm{ka}$, and possibly less than $100 \mathrm{ka}$.

In order to determine an age for the tusk found in deposits of the 1st terrace at Cañada Garañon, fossil corals were collected from the 1st terrace at SRI-27, near Sandy Point on the northwestern part of Santa Rosa Island (Figs. 3, 5) and analyzed for U-series dating. With one exception noted above, corals from SRI-27 are 100\% aragonite (the other is $99 \%$ ), indicating no measurable alteration to calcite. All corals have $U$ contents similar to those of modern and fossil B. elegans described elsewhere from California and Baja California, Mexico (Muhs et al., 2002a, 2006, 2012, 2014a), indicating no significant diagenetic gain or loss of $U$ (Table 2). Concentrations of bulk Th are low and activity ratios of ${ }^{230} \mathrm{Th} /{ }^{232} \mathrm{Th}$ are high, indicating that there is no significant amount of inherited ${ }^{230} \mathrm{Th}$ derived from contaminating detrital minerals that would bias the corals to older apparent ages. Finally, for all but one coral, back-calculated initial ${ }^{234} \mathrm{U} /{ }^{238} \mathrm{U}$ values range from $\sim 1.143$ to $\sim 1.154$, overlapping the range of ${ }^{234} \mathrm{U} /{ }^{238} \mathrm{U}$ found in modern seawater ( 1.141 to 1.155; Delanghe et al., 2002). Sample SRI-27-B has an initial ${ }^{234} \mathrm{U} /{ }^{238} \mathrm{U}$ value of $\sim 1.158$, indicating the possibility of a bias (perhaps as much as $\sim 2-3 \mathrm{ka}$ ) to a slightly older apparent age, based on the models of Gallup et al. (1994) and Thompson et al. (2003). Reduction of the apparent age of SRI-27-B by $\sim 2-3$ ka would result in an age that is still within the range of ages of the other corals, which is $82.9 \pm 0.5 \mathrm{ka}$ to $78.6 \pm 0.5 \mathrm{ka}$. Thus, for five of the six corals, the ages are considered to be reliable with a high degree of confidence. All the coral ages from SRI-27 fall within the same general range of isotopic composition as corals from the 1st terrace on San Nicolas Island, California and the Lighthouse terrace on Punta Banda, Baja California (Fig. 10). All these corals have ages centering on $\sim 80 \mathrm{ka}$ and have a clear correlation to MIS 5.1. A single coral found in deposits of the 2nd terrace of northwestern Santa Rosa Island (SRI-5F; Figs. 3, 5) was also analyzed. This coral has no evidence of $U$ loss or gain or inherited ${ }^{230} \mathrm{Th}$ (Table 2 ). It does, however, have a back-calculated initial ${ }^{234} \mathrm{U} /{ }^{238} \mathrm{U}$ value significantly higher than that of modern seawater. Thus, the apparent age of $\sim 125 \mathrm{ka}$ is likely a maximum estimate; a true age of as young as $\sim 112 \mathrm{ka}$ is possible. If so, the terrace could correlate with either MIS 5.5 or MIS 5.3 .

Thus, the tusk in marine deposits of the 1st terrace at Cañada Garañon (SRI-5G) can be no younger than $\sim 80 \mathrm{ka}$. The maximum possible age of the tusk is unknown. The mammoth it belonged to could have 

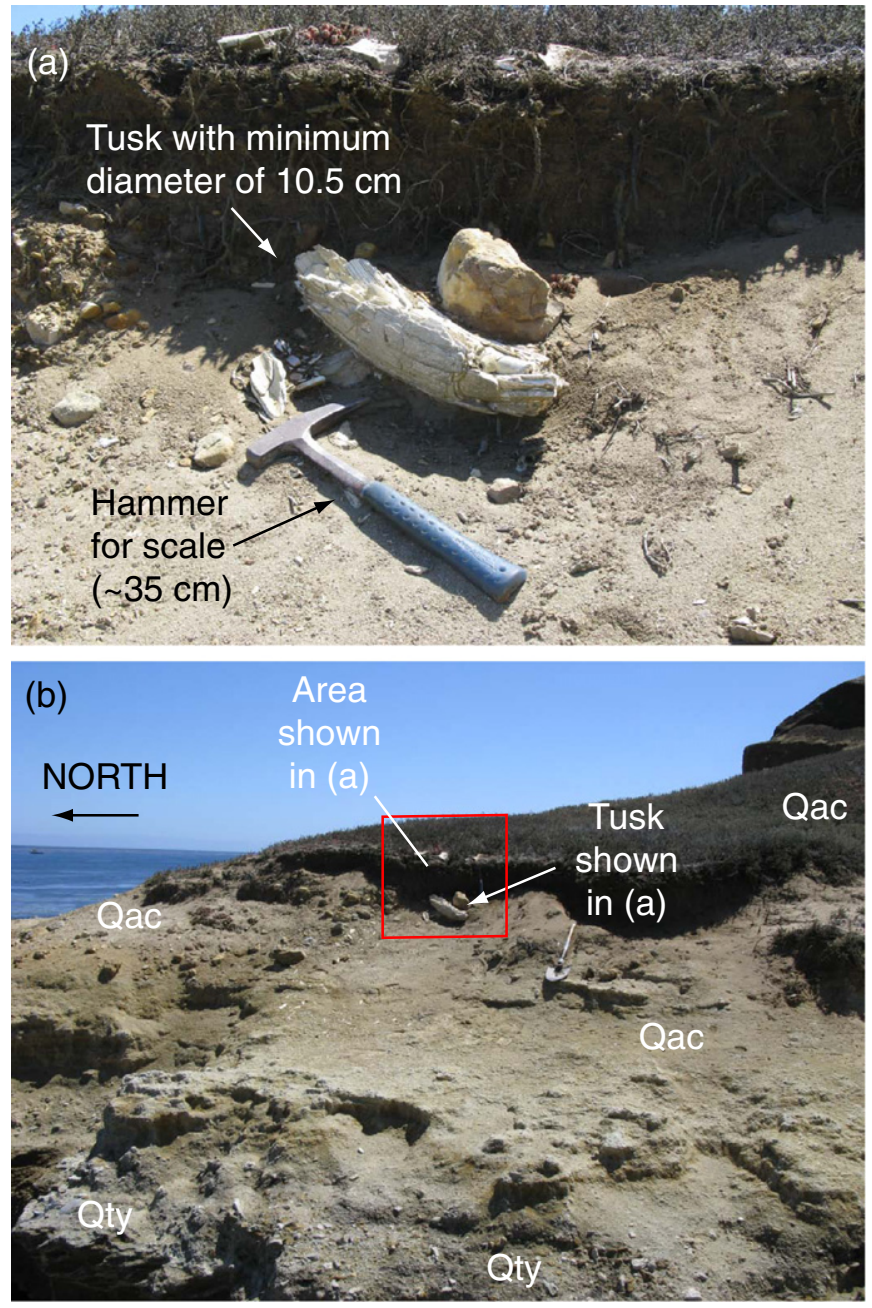

Figure 9. Photograph of probable Mammuthus columbi tusk, not in stratigraphic context, but probably derived from terrestrial deposits overlying the 1st marine terrace at the mouth of Cañada Garañon, Santa Rosa Island (see Fig. 5b). (a) Close-up of tusk; (b) geologic units near the tusk. Qac, alluvium and/or colluvium; Qty, marine terrace deposits, younger.

been living on Santa Rosa Island during the MIS 5.1 high-sea stand around $80,000 \mathrm{ka}$, or some earlier time, after which the tusk was reworked into the marine terrace deposits. The Cañada Garañon tusk and the tusk found east of Lobo Canyon confirm, however, the presence of Mammuthus on the Channel Islands well before the last glacial period, MIS 2.

\section{Discussion}

Mammoth chronology, Channel Islands paleogeography, and immigrations

In the Quaternary, North America hosted at least four species of mammoths, Mammuthus meridionalis Nesti 1825, M. columbi, M. exilis, and Mammuthus primigenius (Blumenbach, 1799) (Agenbroad, 1984, 2005) and possibly Mammuthus trogontherii (Lister and Bahn, 2007). $M$. trogontherii is thought to have arrived in North America around 1.5 Ma (Lister and Bahn, 2007). However, mammoths that are likely older than 1.5 Ma have been found in the Leisey Shell Bed of Florida (Webb et al., 1989; Webb and Dudley, 1995). The original Sr-isotopic age estimates of shells from the mammoth-bone-bearing bed at Leisey were 1.8-1.6 Ma (Webb et al., 1989). Using the updated Sr-isotopic age calibration of Howarth and McArthur (1997), we recalculate these ages to be 2.2-1.8 Ma. Thus, mammoths have been in North America for much or all of the Quaternary.

According to Lister and Bahn (2007), M. meridionalis was apparently the ancestor of $M$. trogontherii (the steppe mammoth, found in Eurasia), which in turn was the ancestor of both M. primigenius (the wooly mammoth) and $M$. columbi (the Columbian mammoth). Whereas M. primigenius appears to have been an immigrant to North America, M. columbi apparently evolved in North America, as it is not found on any other continent. Although $M$. columbi formerly was considered to be only a late Pleistocene (= Rancholabrean North American Land Mammal Age) species (Maglio, 1973; Agenbroad, 1984), it has been found in association with M. meridionalis in beds dated to $\sim 1.1-0.9 \mathrm{Ma}$ in Anza-Borrego Desert State Park, in eastern San Diego County, California (McDaniel and Jefferson, 2006). M. exilis, the pygmy mammoth, evolved from M. columbi, the only mainland mammoth with a fossil record on the Channel Islands (Johnson, 1978; Madden, 1981; Agenbroad, 2012).

As alluded to earlier, mammoths most likely reached the Channel Islands from mainland California by swimming rather than a landbridge crossing (Johnson, 1978, 1980; Junger and Johnson, 1980; Wenner and Johnson, 1980). Johnson's (1978) inference of mammoths reaching the Channel Islands by swimming is based on modern observations of the swimming abilities of Asian and Indian elephants, the closest living relatives of mammoths. Based on swim duration and speed estimates, Johnson $(1978,1980)$ documents probable $13-16 \mathrm{~km}$, nonstop swims of modern elephants, with one case of a 48-km traverse,

Table 1

Radiocarbon ages of modern and fossil Helminthoglypta ayresiana, San Miguel Island and Santa Rosa Island.

\begin{tabular}{|c|c|c|c|c|c|c|c|c|}
\hline WW\# & CAMS\# & Field \# & Coordinates & Location & $\delta^{13} \mathrm{C}(\mathrm{o} / \mathrm{oo})$ & ${ }^{14} \mathrm{C}$ age (yr BP) & \pm & $\begin{array}{l}\text { Cal yr BP } \\
\text { ( } 2 \text { sigma) }\end{array}$ \\
\hline \multicolumn{9}{|c|}{ Modern } \\
\hline 9449 & 161894 & SMI-303-1 & $\mathrm{N} 34^{\circ} 03.249^{\prime} \mathrm{W} 120^{\circ} 22.077^{\prime}$ & San Miguel Island, CA & -7.5 & 1040 & 25 & $921-1043$ \\
\hline 9450 & 161895 & SMI-303-2 & $\mathrm{N} 34^{\circ} 03.249^{\prime} \mathrm{W} 120^{\circ} 22.077^{\prime}$ & San Miguel Island, CA & -6.0 & 570 & 25 & $531-641$ \\
\hline 9451 & 161896 & SMI-309-1 & $\mathrm{N} 34^{\circ} 02.664^{\prime} \mathrm{W} 120^{\circ} 21.108^{\prime}$ & San Miguel Island, CA & -8.7 & 810 & 25 & $681-768$ \\
\hline 9452 & 161897 & SMI-309-2 & $\mathrm{N} 34^{\circ} 02.664^{\prime} \mathrm{W} 120^{\circ} 21.108^{\prime}$ & San Miguel Island, CA & -9.2 & 585 & 25 & $538-647$ \\
\hline 9453 & 161898 & SMI-309-3 & $\mathrm{N} 34^{\circ} 02.664^{\prime} \mathrm{W} 120^{\circ} 21.108^{\prime}$ & San Miguel Island, CA & -7.4 & 705 & 25 & $569-687$ \\
\hline \multicolumn{9}{|l|}{ Fossil } \\
\hline 9849 & 166108 & SRI-1F-75 & $\mathrm{N} 34^{\circ} 01.19^{\prime} \mathrm{W} 120^{\circ} 05.48^{\prime}$ & Santa Rosa Island, CA & -5.4 & 41,770 & 620 & $\mathrm{~N} / \mathrm{A}^{*}$ \\
\hline 9850 & 166109 & SRI-1F-70 & $\mathrm{N} 34^{\circ} 01.19^{\prime} \mathrm{W} 120^{\circ} 05.48^{\prime}$ & Santa Rosa Island, CA & -3.5 & 40,950 & 560 & $N / A^{*}$ \\
\hline 9851 & 166110 & SRI-1F-100 & $\mathrm{N} 34^{\circ} 01.19^{\prime} \mathrm{W} 120^{\circ} 05.51^{\prime}$ & Santa Rosa Island, CA & -6.2 & 43,460 & 750 & $\mathrm{~N} / \mathrm{A}^{*}$ \\
\hline 9852 & 166111 & SRI-1F-127 & $\mathrm{N} 34^{\circ} 01.19^{\prime} \mathrm{W} 120^{\circ} 05.51^{\prime}$ & Santa Rosa Island, CA & -6.2 & 40,910 & 550 & $\mathrm{~N} / \mathrm{A}^{*}$ \\
\hline 9853 & 166112 & SRI-1F-143 & $\mathrm{N} 34^{\circ} 01.19^{\prime} \mathrm{W} 120^{\circ} 05.51^{\prime}$ & Santa Rosa Island, CA & -7.8 & 46,200 & 1100 & $\mathrm{~N} / \mathrm{A}^{*}$ \\
\hline
\end{tabular}

Samples were processed at the ${ }^{14} \mathrm{C}$ laboratory of the U. S. Geological Survey in Reston, Virginia.

${ }^{14} \mathrm{C}$ ages were determined at the Center for Accelerator Mass Spectrometry (CAMS), Lawrence Livermore National Laboratory, Livermore, California.

The WW number is the identification assigned to a sample by the USGS ${ }^{14} \mathrm{C}$ laboratory.

The ${ }^{14} \mathrm{C}$ ages are in radiocarbon years BP with one-sigma errors. $\delta^{13} \mathrm{C}$ values are given in per mil relative to VPDB.

Calibrated age ranges calculated using CALIB 7.0 software (Stuiver and Reimer, 1993) in conjunction with the INTCAL13 atmospheric data set (Reimer et al., 2013).

* Fossil samples are interpreted to be older than the upper age limit for radiocarbon dating. 
Table 2

$\mathrm{U}$ and Th concentrations, isotopic activity ratios (AR) and U-series ages of corals (Balanophyllia elegans), Santa Rosa Island, California.

\begin{tabular}{|c|c|c|c|c|c|c|c|c|c|c|c|c|c|}
\hline Sample ID & $\begin{array}{l}\text { Aragonite } \\
\text { (wt. \%) }\end{array}$ & $\begin{array}{l}\mathrm{U} \\
\mathrm{ppm}\end{array}$ & $+/-$ & $\begin{array}{l}{ }^{232} \mathrm{Th} \\
\mathrm{ppm}\end{array}$ & $\begin{array}{l}{ }^{230} \mathrm{Th} /{ }^{232} \mathrm{Th} \\
\mathrm{AR}\end{array}$ & $\begin{array}{l}{ }_{A R}^{234} U /{ }^{238} U \\
\text { AR }\end{array}$ & $+1-$ & $\begin{array}{l}{ }^{230} \mathrm{Th} /{ }^{238} \mathrm{U} \\
\mathrm{AR}\end{array}$ & $+1-$ & $\begin{array}{l}{ }^{230} \mathrm{Th} /{ }^{238} \mathrm{U} \text { age } \\
\text { (ka) }\end{array}$ & $+1-$ & $\begin{array}{l}{ }^{234} \mathrm{U} /{ }^{238} \mathrm{U} \\
\text { initial AR }\end{array}$ & $+1-$ \\
\hline \multicolumn{14}{|c|}{ Western Santa Rosa Island, 1st terrace } \\
\hline SRI-27-A & 100 & 4.66 & 0.11 & 0.0041 & 2016 & 1.1139 & 0.0019 & 0.5846 & 0.0021 & 79.9 & 0.5 & 1.1427 & 0.0023 \\
\hline SRI-27-C & 99 & 4.17 & 0.12 & 0.0061 & 1218 & 1.1226 & 0.0016 & 0.5908 & 0.0017 & 80.1 & 0.4 & 1.1537 & 0.0019 \\
\hline SRI-27-D & 100 & 4.49 & 0.14 & 0.0030 & 2636 & 1.1173 & 0.0015 & 0.5817 & 0.0023 & 78.9 & 0.5 & 1.1466 & 0.0018 \\
\hline SRI-27-E & 100 & 3.18 & 0.11 & 0.0039 & 1471 & 1.1136 & 0.0020 & 0.5996 & 0.0021 & 82.9 & 0.5 & 1.1436 & 0.0024 \\
\hline SRI-27-B & 100 & 3.70 & 0.11 & 0.0028 & 2485 & 1.1251 & 0.0025 & 0.6107 & 0.0025 & 83.8 & 0.6 & 1.1585 & 0.0030 \\
\hline SRI-27-G & 100 & 3.86 & 0.13 & 0.0034 & 2007 & 1.1234 & 0.0030 & 0.5839 & 0.0022 & 78.6 & 0.5 & 1.1541 & 0.0036 \\
\hline \multicolumn{14}{|c|}{ Western Santa Rosa Island, 2nd terrace } \\
\hline SRI-5 F & $\geq 95$ & 4.59 & 0.11 & 0.0164 & 675 & 1.1417 & 0.0014 & 0.7960 & 0.0024 & 125.5 & 0.8 & 1.2019 & 0.0018 \\
\hline \multicolumn{14}{|c|}{ Eastern Santa Rosa Island, lowermost terrace } \\
\hline SRI-1-B & 100 & 4.19 & 0.11 & 0.0027 & 3419 & 1.1163 & 0.0018 & 0.7303 & 0.0026 & 112.7 & 0.8 & 1.1599 & 0.0023 \\
\hline SRI-1-B dup \#1 & 100 & 4.19 & 0.11 & 0.0027 & 3411 & 1.1166 & 0.0019 & 0.7318 & 0.0031 & 113.1 & 0.9 & 1.1604 & 0.0025 \\
\hline SRI-1-C & 100 & 4.11 & 0.11 & 0.0100 & 902 & 1.1164 & 0.0019 & 0.7219 & 0.0021 & 110.5 & 0.6 & 1.1590 & 0.0024 \\
\hline SRI-1-D & 100 & 3.41 & 0.12 & 0.0060 & 1256 & 1.1206 & 0.0019 & 0.7347 & 0.0017 & 113.1 & 0.6 & 1.1659 & 0.0025 \\
\hline
\end{tabular}

All errors are 2-sigma; all samples analyzed in laboratories of the U.S. Geological Survey, Denver, Colorado USA.

Ages calculated with new half-lives of ${ }^{230} \mathrm{Th}=75,584$ and ${ }^{234} \mathrm{U}=245,620$ (Cheng et al., 2013).

although it was a forced swim. Based on these observations, it is therefore possible that mammoths could have managed a swim from the mainland to the Channel Islands with the present, shortest interglacial mainland-island distances of $\sim 20 \mathrm{~km}$ (to East Anacapa Island) or $\sim 31 \mathrm{~km}$ (to Santa Cruz Island).

Nevertheless, there are more favorable times for mammoth crossings by swimming. Johnson (1978) pointed out that the most likely times for mammoth immigration to the Channel Islands would be during glacial periods, when the mainland-to-island distance would be at a minimum. The record of submerged fossil coral reefs from Barbados indicates a eustatic sea-level lowering (relative to present) of $\sim 120 \mathrm{~m}$ during the LGM (Fairbanks, 1989; Bard et al., 1990), or possibly as much as $140 \mathrm{~m}$ (Peltier and Fairbanks, 2006). It is now known, however, that glacial isostatic adjustment (GIA) effects result in a different relative sea level record on the California coast compared to Barbados. Recent models show an LGM sea-level lowering of only $~ 95 \mathrm{~m}$, relative to present, for San Nicolas Island (Muhs et al., 2012) and 101-111 m on the northern Channel Islands (Clark et al., 2014; Reeder-Myers et al., 2015).

Using two different estimates of LGM sea-level lowering ( $120 \mathrm{~m}$ vs. $\sim 100 \mathrm{~m}$ below present), two alternative maps of the paleogeography of the Channel Islands and the Santa Barbara Channel region during LGM time were generated. By either estimate of LGM sea-level lowering, the four northern islands would have been connected, comprising a large, single island that Orr (1968) called "Santarosae" (Fig. 11a). There would be little difference in the distance from mainland California to Santarosae during the LGM in either of these two paleogeographic reconstructions. Thus, mammoths would have had to swim from the mainland only to what is now the eastern end of Anacapa Island, a distance of $\sim 7.2 \mathrm{~km}$. During an interglacial period such as the present one, the mainland-to-island distance increases by about a factor of three from the mainland to Anacapa Island. For an interglacial swim to Santa Cruz Island (where mammoth colonization likely would have a greater chance of success compared to tiny Anacapa Island), the mainland-to-island distance is greater than the LGM distance by about a factor of five. Thus, Johnson's (1978) model of a glacial-period timing for mammoth immigration is supported by either estimate of LGM sealevel lowering. A remaining question, then, is which glacial period set the stage for the earliest mammoth immigration.

Most previous estimates of the timing of earliest mammoth arrival on the northern Channel Islands have been of a speculative nature. Valentine and Lipps (1967) referred to mammoth remains that had been found in marine terrace deposits of the Channel Islands, perhaps based on the Santa Rosa Island observations by Orr (1960), and suggested that the period of dwarfing (M. columbi to M. exilis) may have preceded the Sangamon (= last interglacial = MIS 5) period. Orr (1967) considered that mammoths had been on the Channel Islands since "Illinoian" time (= penultimate glacial period = MIS 6), but did not provide any details as to how this age estimate was made. As discussed above, Orr (1960) pointed out that mammoth remains occur in what he called the marine facies of the Garañon Member of the Santa Rosa Island Formation, confirmed by the present study. In a later summary, Orr (1968) considered this marine deposit to be $200 \mathrm{ka}$ or more, based on U-series dating of mollusks. However, it is now known that mollusks are unsuitable for U-series dating (Kaufman et al., 1971; Edwards et al., 2003) and our new age estimates disagree with the $\geq 200 \mathrm{ka}$ age for these deposits. Madden (1981) reported U-series ages of $\sim 64 \mathrm{ka}$ and $\sim 28 \mathrm{ka}$ for $M$. columbi remains from the Channel Islands, but U-series ages on bone or teeth are not reliable either (Schwarcz and Blackwell, 1992). Lister and Bahn (2007) thought that mammoth immigration to the Channel Islands took place some time after $\sim 100 \mathrm{ka}$, but gave no information regarding their basis for this age estimate.

Direct dating of the 1st marine terrace to $80 \mathrm{ka}$ on northwestern Santa Rosa Island confirms that mammoths were present on Santa Rosa Island prior to the last glacial period. Supporting data come from the tusk east of Lobo Canyon that is at least $\sim 40 \mathrm{ka}$, but younger than $\sim 120-100 \mathrm{ka}$. These data support the Johnson (1978) model that immigration of mammoths to the northern Channel Islands could have taken place prior to the last glacial period, assuming a favorable paleogeography. Marine isotope stage 5.1 at $\sim 80$ ka was a time of relatively high sea level. The magnitude of sea level, relative to present, during MIS 5.1 varies from coast to coast, depending on GIA effects (Potter and Lambeck, 2003; Muhs et al., 2012). At localities relatively close to North American ice sheets, such as the U.S. Atlantic Coastal Plain and Bermuda, local sea level was above present during MIS 5.1 (Muhs et al., 2002b; Wehmiller et al., 2004). Farther from the ice sheets, but still along North American coasts, marine terrace records from Florida and California indicate a paleo-sea level of about $-15 \mathrm{~m}$ to $-11 \mathrm{~m}$ during MIS 5.1 (Toscano and Lundberg, 1999; Muhs et al., 2012). Localities distant from North American ice sheets, such as Barbados, have uplifted coral reef terrace records indicating a paleo-sea level of about $-20 \mathrm{~m}$ relative to present at $\sim 80 \mathrm{ka}$ (Cutler et al., 2003; Potter et al., 2004; Schellmann and Radtke, 2004). Any of these estimates would yield a southern California coastal paleogeography only slightly different than today's, with a significant water gap between the California mainland and Eastern Anacapa Island. The super-island Santarosae would not have existed during MIS 5.1. 
(a)

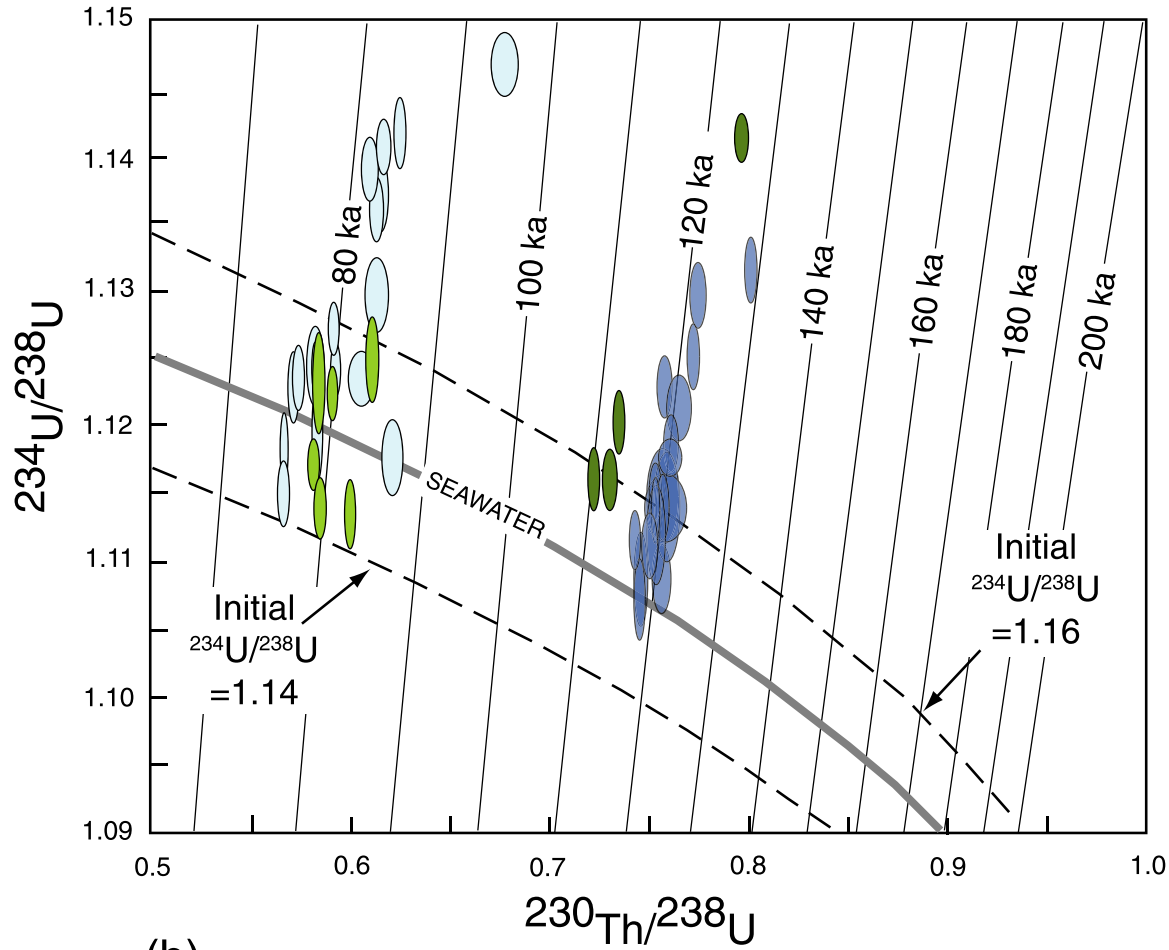

(b)

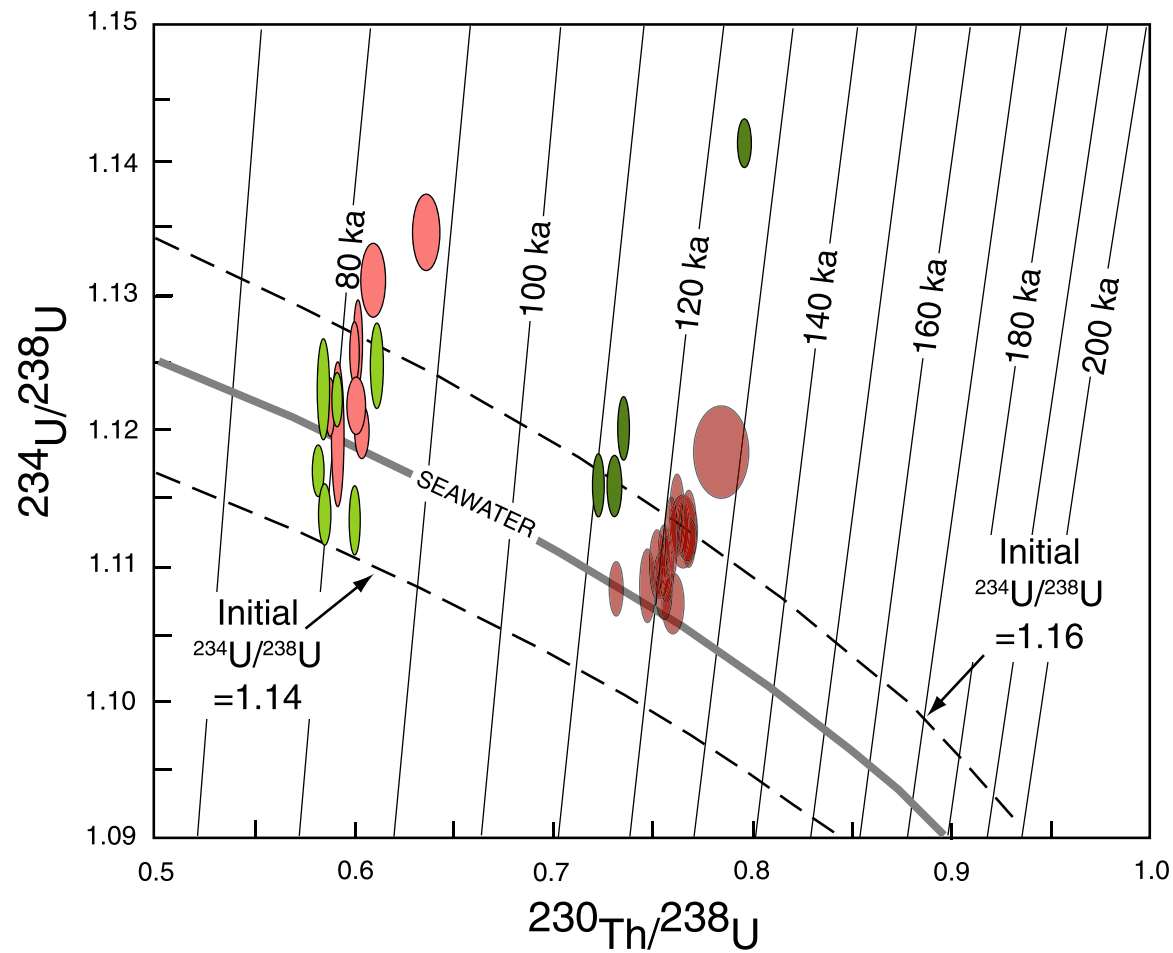

Santa Rosa Island, terrace 1 (SRI-27)

Santa Rosa Island, terrace 2 (SRI-5F) and uncertain (SRI-1)

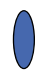

San Nicolas Island, terrace 1

San Nicolas Island, terrace $2 a$

Santa Rosa Island, terrace 1 (SRI-27)

Santa Rosa Island, terrace 2 (SRI-5F) and uncertain (SRI-1)

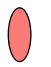

Punta Banda, Lighthouse, terrace 1

Punta Banda, Sea Cave, terrace 2

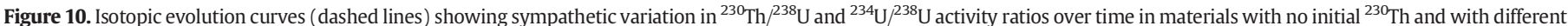

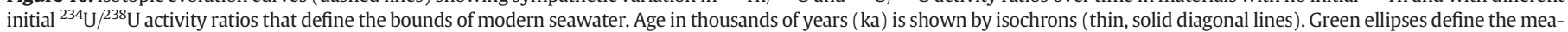

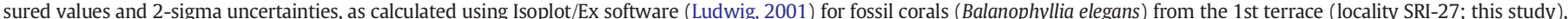

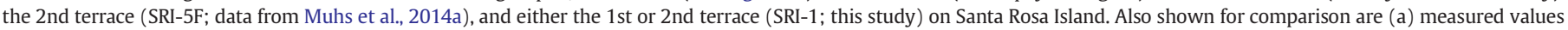

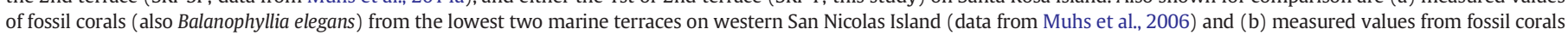
(also Balanophyllia elegans) from the 1st (Lighthouse) and 3rd (Sea Cave) terraces at Punta Banda, Baja California, Mexico (data from Muhs et al., 2002a).

Could mammoths have arrived on the Channel Islands just prior to the $\sim 80$ ka high-sea stand? The southern California sea-level model presented by Muhs et al. (2012) indicates that during MIS 5.2 ( 90-85 ka), the period just prior to the formation of the tusk-bearing 1st terrace (80 ka) on Santa Rosa Island, paleo-sea level could have been about $-29 \mathrm{~m}$, relative to today. A map of the Santa Barbara Channel region 

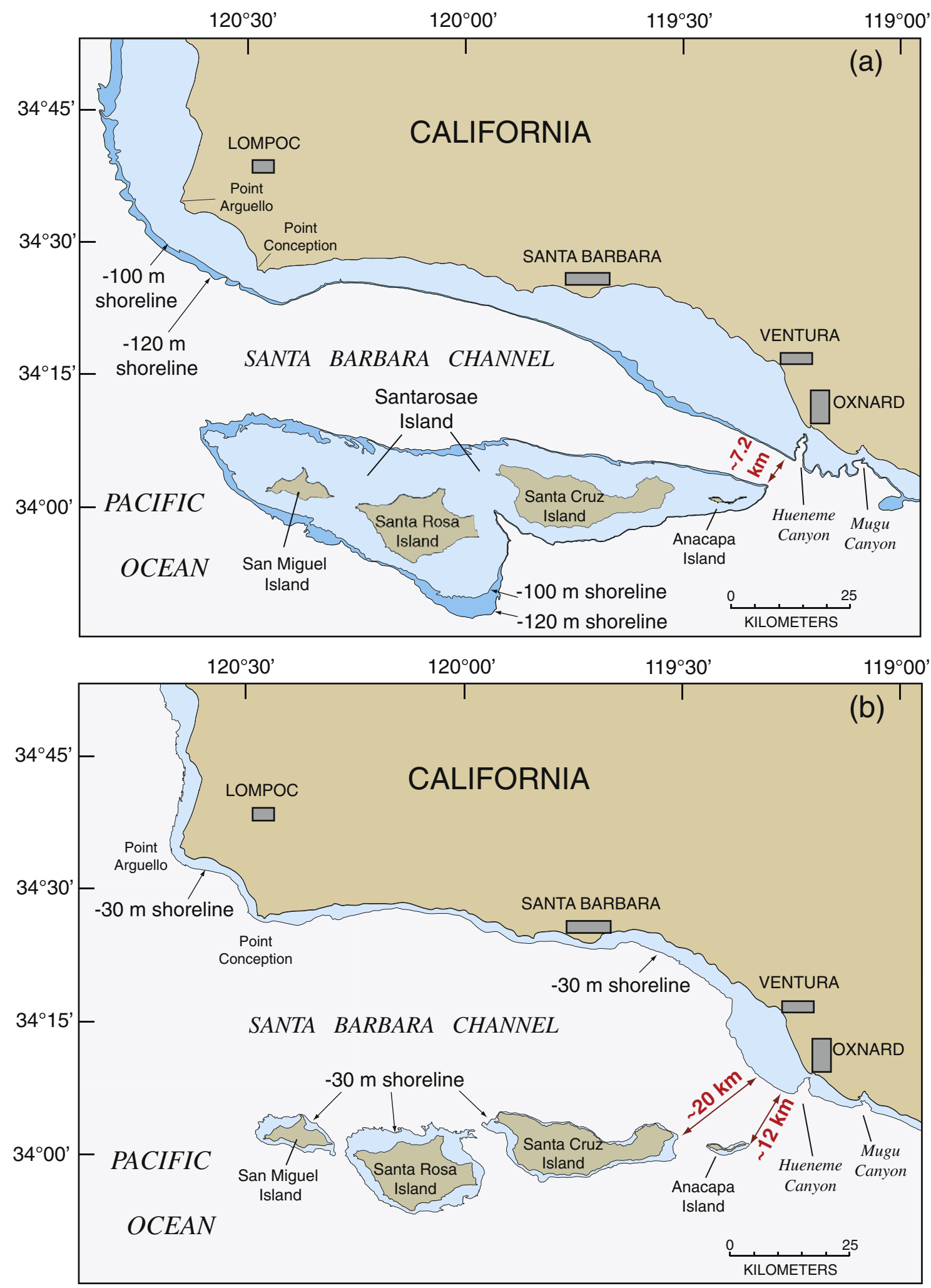

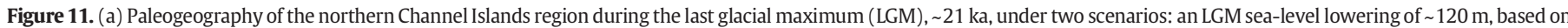

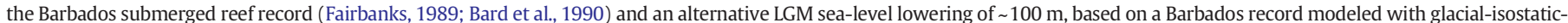

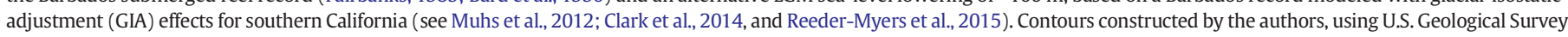

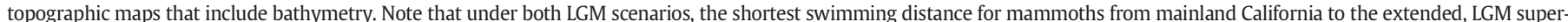

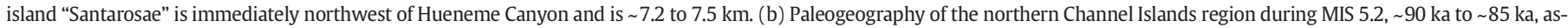

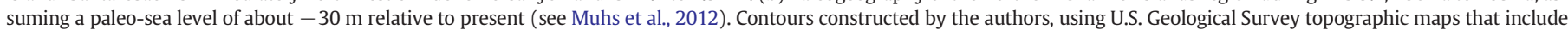
bathymetry. 
at MIS 5.2 with this lower sea level also yields a paleogeography little different from that of today (Fig. 11b). Santarosae would not have existed then and the mainland-to-island distance (to eastern Santa Cruz Island) would have been $\sim 20 \mathrm{~km}$.

It seems that more likely periods of pre-LGM mammoth immigration would have been during either MIS 6, around $150 \mathrm{ka}$, or MIS 8, around $250 \mathrm{ka}$, based on both the Red Sea and Cocos Ridge oxygen isotope records of sea level (Fig. 12). While it is true that during MIS 6 or MIS 8 the northern Channel Islands would not have experienced as much cumulative uplift as they ultimately did by MIS 2 time, late Quaternary uplift rates of the northern Channel Islands are modest, based on data from western Santa Cruz Island (Pinter et al., 1998) and

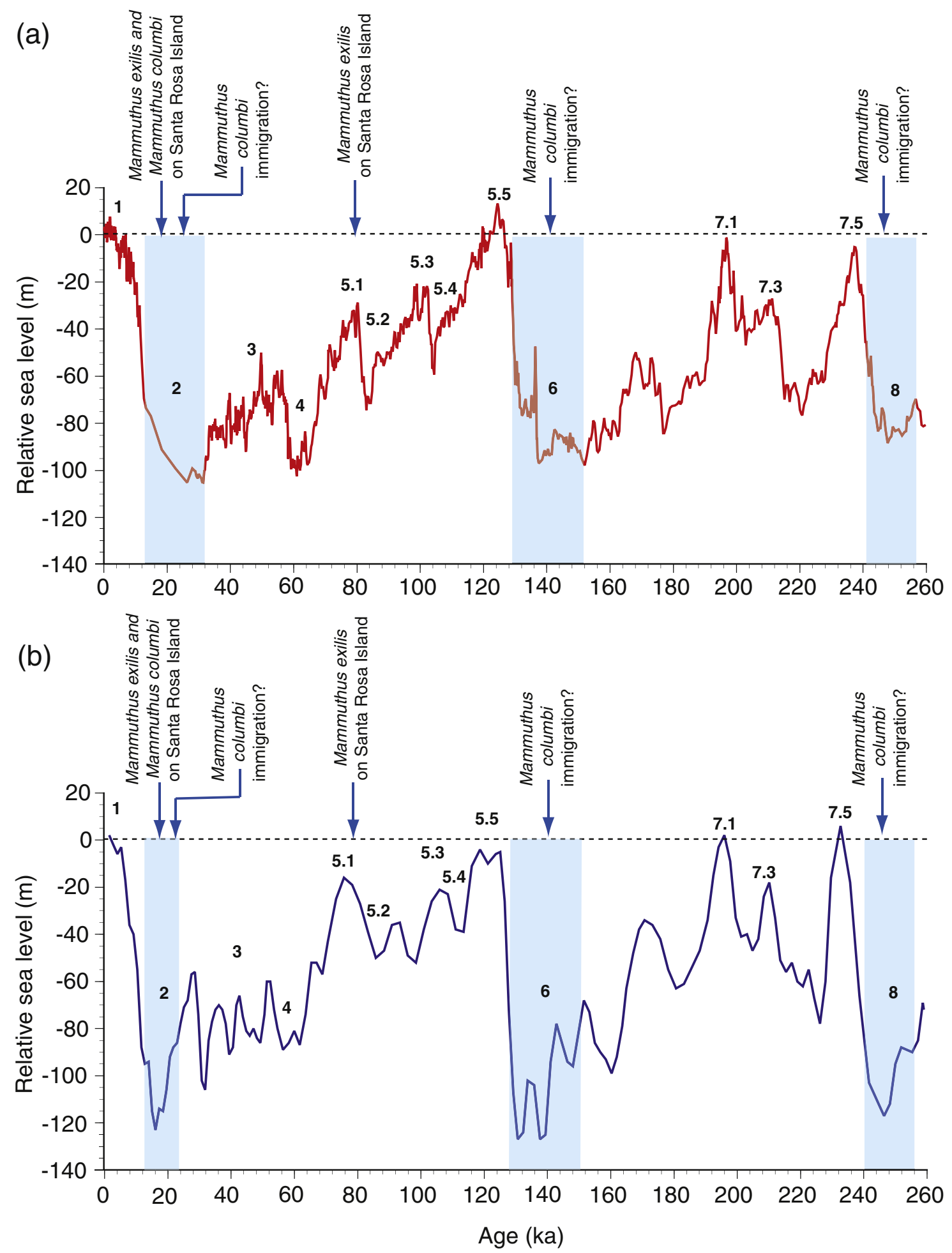

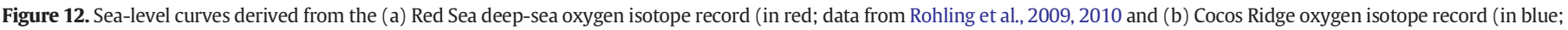

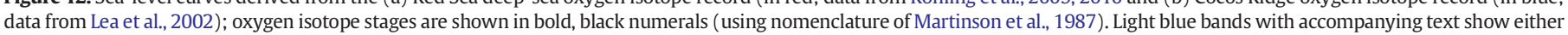
confirmed times of Mammuthus columbi and M. exilis presence on the Channel Islands or hypothesized times of M. columbi immigration from the California mainland to the islands. 
San Miguel Island and Santa Rosa Island (Muhs et al., 2014a). Because the 2nd terrace near Cañada Garañon is likely 120 ka (Fig. 5c; Table 2) and paleo-sea level at that time was about $+6 \mathrm{~m}$ (Muhs et al., 2002a, 2011), the shoreline angle elevation ( $+24 \mathrm{~m}$ ) yields a relatively low uplift rate of $0.15 \mathrm{~m} / \mathrm{ka}$ for this part of Santa Rosa Island. Thus, if the Red Sea and Cocos Ridge records constitute at least firstorder approximations of Quaternary sea level fluctuations, and if the estimates of modest late Quaternary uplift rates for the northern Channel Islands are correct, the distance from mainland California to the eastern end of an ancient Santarosae island during MIS 8 or MIS 6 likely would have been only slightly greater than during MIS 4 or MIS 2. Marine isotope stage 6 corresponds to the penultimate, or Illinoian glaciation of North America. During this glacial advance, the Laurentide ice sheet reached its southernmost extent in midcontinental North America (Flint, 1971), consistent with sea level being relatively low during MIS 6. Ironically then, Orr's (1967) estimate of the presence of mammoths on the Channel Islands since Illinoian time, although based on what is now known to be an unreliable dating method, may actually be correct.
It is worth pointing out, however, that on a tectonically rising continental coast adjacent to tectonically rising islands, mainland-to-island distances will necessarily decrease over time. Whereas uplift rates on the northern Channel Islands are relatively low (Pinter et al., 1998; Muhs et al., 2014a), uplift rates on the mainland opposite the islands are relatively high (Sarna-Wojcicki et al., 1987; Gurrola et al., 2014). Therefore, a terrace of a given age on the mainland will be at a higher elevation than a terrace of the same age on the islands (Fig. 13). Nevertheless, in the early-to-middle Quaternary, there would have been less cumulative uplift on both the Channel Islands and the mainland. Hence, swimming distances for mammoths, even during glacial periods, would have been greater than during the LGM (Fig. 13). It is not known when conditions of long-term uplift might have finally reached a threshold such that during a glacial period, the mainland-to-island distance was short enough that mammoths might have been tempted to make the crossing. Thus, although the work presented here indicates that mammoth immigration certainly preceded the LGM, and recent studies demonstrate that M. columbi has been in California for upwards

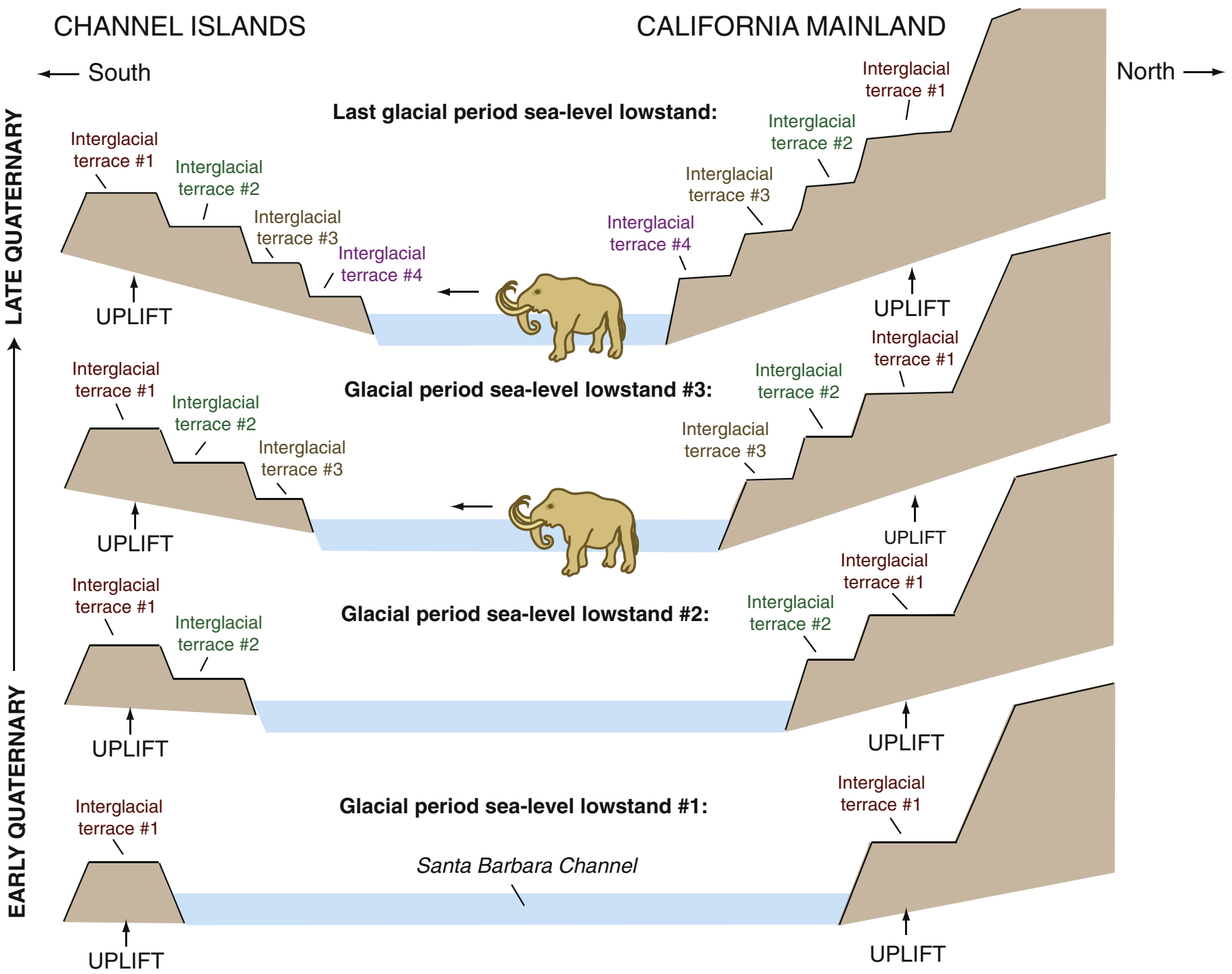

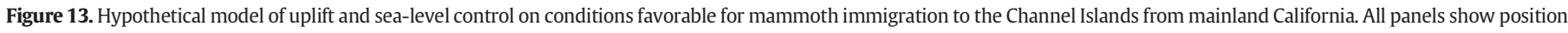

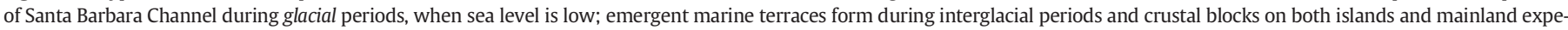

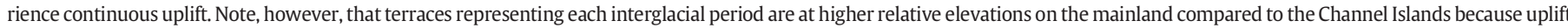

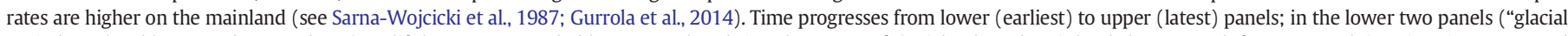

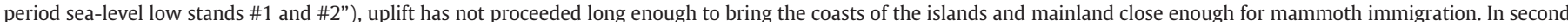

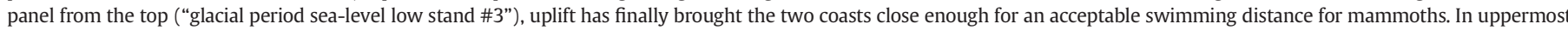

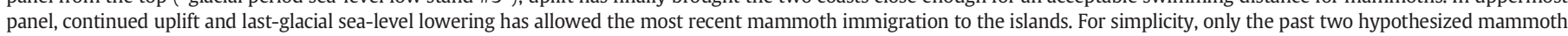
crossings are illustrated (MIS 2 and 6), but a mammoth crossing during MIS 8 is also possible (see Fig. 12 and discussion in text). 
of a million years (McDaniel and Jefferson, 2006), it does not necessarily follow that mammoth immigrations took place during each glacial period of the Quaternary. In support of this line of reasoning, repeated field studies of pre-MIS 5 marine terrace deposits on San Miguel Island, Santa Rosa Island, and Santa Cruz Island over the past decade have failed to yield mammoth remains.

\section{Implications for causes of mammoth extinction}

One of the most intriguing questions in the Quaternary history of North America is the cause for the disappearance of large mammals, or megafauna, near the close of the Pleistocene. Among the many genera that became extinct at this time in North America are mammoths, with the exception of some lone survivors that date to the midHolocene on remote St. Paul Island in the Pribilof Islands of Alaska (Guthrie, 2004; Veltre et al., 2008). The possible causes of megafaunal extinction at the close of the Pleistocene have been hotly debated, and as the literature on this topic is voluminous, only a brief summary is given here. Three main mechanisms of extinction have been proposed for North America: (1) the human arrival hypothesis (Martin, 1967, 1984, 2005; Haynes, 2013; Sandom et al., 2014, and references therein), wherein humans, newly arrived from Asia, extirpated an unwary North American fauna; (2) the climate change hypothesis, in which the shift from a glacial to an interglacial climate brought about extraordinary changes in ecosystems such that megafaunal species were unable to adapt (Graham and Lundelius, 1984; Grayson and Meltzer, 2002, 2003 and references therein); and (3) the cosmic catastrophic event hypothesis, where an impact or airburst of an extraterrestrial body (comet or meteor) is thought to have brought about dramatic changes in climate, widespread fires, and demise of human (Clovis culture) and animal (megafauna) populations (Firestone et al., 2007; Kennett et al., 2008, 2009). Other investigators have pointed out the possibility of a combination of human-caused and climate-related causes of extinction (see discussion in Barnosky et al., 2004). Although all three mechanisms are controversial, the extraterrestrial impact hypothesis has received a significant amount of criticism (e.g., Daulton et al., 2010; Pinter et al., 1998, 2011; Holliday et al., 2014; Meltzer et al., 2014) and is not considered further here. No attempt is made to discuss the pros and cons of the human vs. climate change causes for megafaunal extinction in North America, but some of the findings presented here have relevance to the debate on these two causes for mammoth extinction specifically on the Channel Islands.
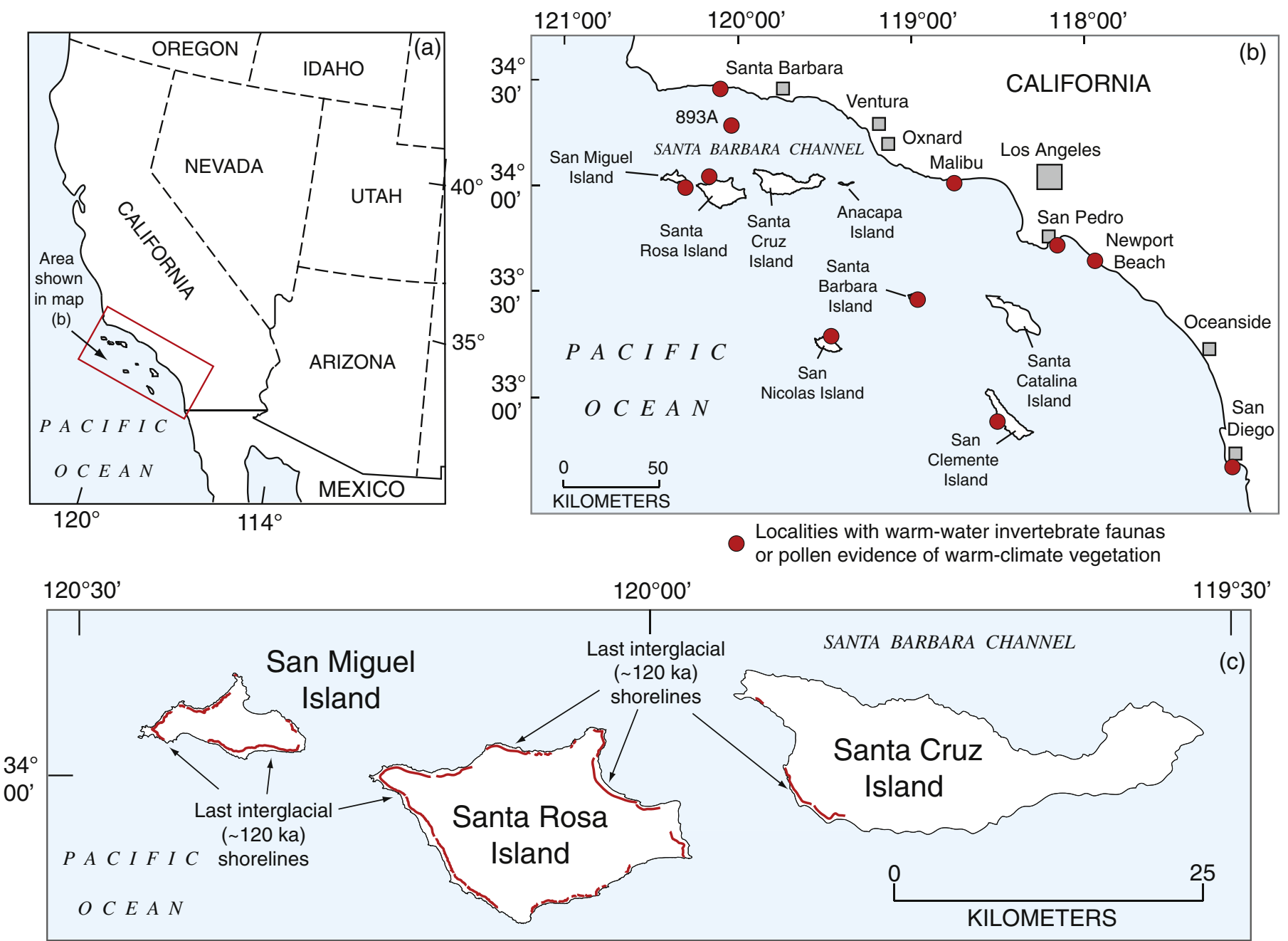

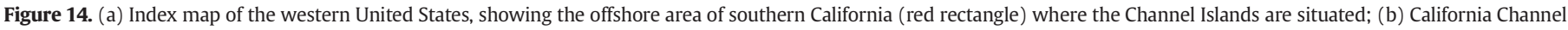

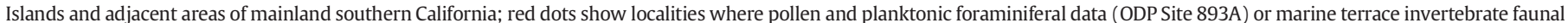

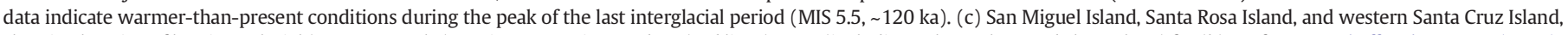

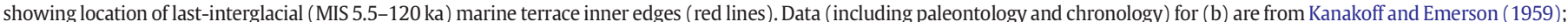

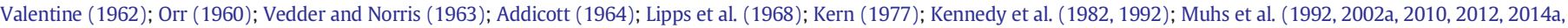

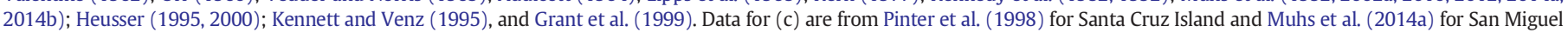
Island and Santa Rosa Island. 
There is little question that early humans in North America hunted proboscideans. Indeed, Mammuthus and Mammut are two of the very few megafaunal taxa for which there is unequivocal archeological evidence indicating human predation, and there are at least a dozen such sites with mammoth remains in North America (see compilations in Grayson and Meltzer, 2002, 2003). Early investigators on the Channel Islands emphasized the association of what were interpreted to be possible human-caused fire areas, primarily on Santa Rosa Island, and sometimes found in association with mammoth remains (Berger and Orr, 1966; Orr and Berger, 1966; Orr, 1968; Berger, 1980). However, there have been objections to the interpretation of these fire areas as human-caused (Wendorf, 1982; Rick et al., 2012a; Pigati et al., 2014). Orr and Berger (1966) also report mammoth remains from Santa Rosa Island that show signs of "butchering" and "battering," although no photographic evidence is offered in this study to support these interpretations. Nevertheless, Agenbroad et al. (2005) point out that within the limits of analytical uncertainty for radiocarbon dating, there is potentially a slight temporal overlap between the youngest dated $M$. exilis on the
Channel Islands and the oldest (thus far) dated human bone in North America, also from the Channel Islands.

Despite the possible temporal overlap of humans and mammoths, there is currently no direct evidence that humans hunted mammoths on the Channel Islands (Rick et al., 2012b). Martin and Steadman (1999) suggest that a "commando raid" type of scenario is possible for Crete, Ireland, Wrangel Island (Siberia), and the Channel Islands, wherein stone-age hunters overrun an island, slaughter preferred prey (such as mammoths), quickly discover they cannot sustain an existence, and depart without leaving any archeological evidence of their visit. In addition, it is important to recognize that with post-glacial sea level rise in the latest Pleistocene/earliest Holocene, many potentially important archeological sites on the northern Channel Islands would now be submerged on what are presently the insular shelves (Clark et al., 2014; Reeder-Myers et al., 2015). Nevertheless, Rick et al. (2012b) concluded that climate change and ecological disturbance were likely the main causes for mammoth extinction on the Channel Islands. These investigators also point out that with post-glacial sea level rise, one consequence (a)

$\delta^{18} \mathrm{O}(\mathrm{o} / \mathrm{oO})$ (b)

Pinus (\%) (c)

Quercus (\%) (d)

\section{Compositae (\%)}

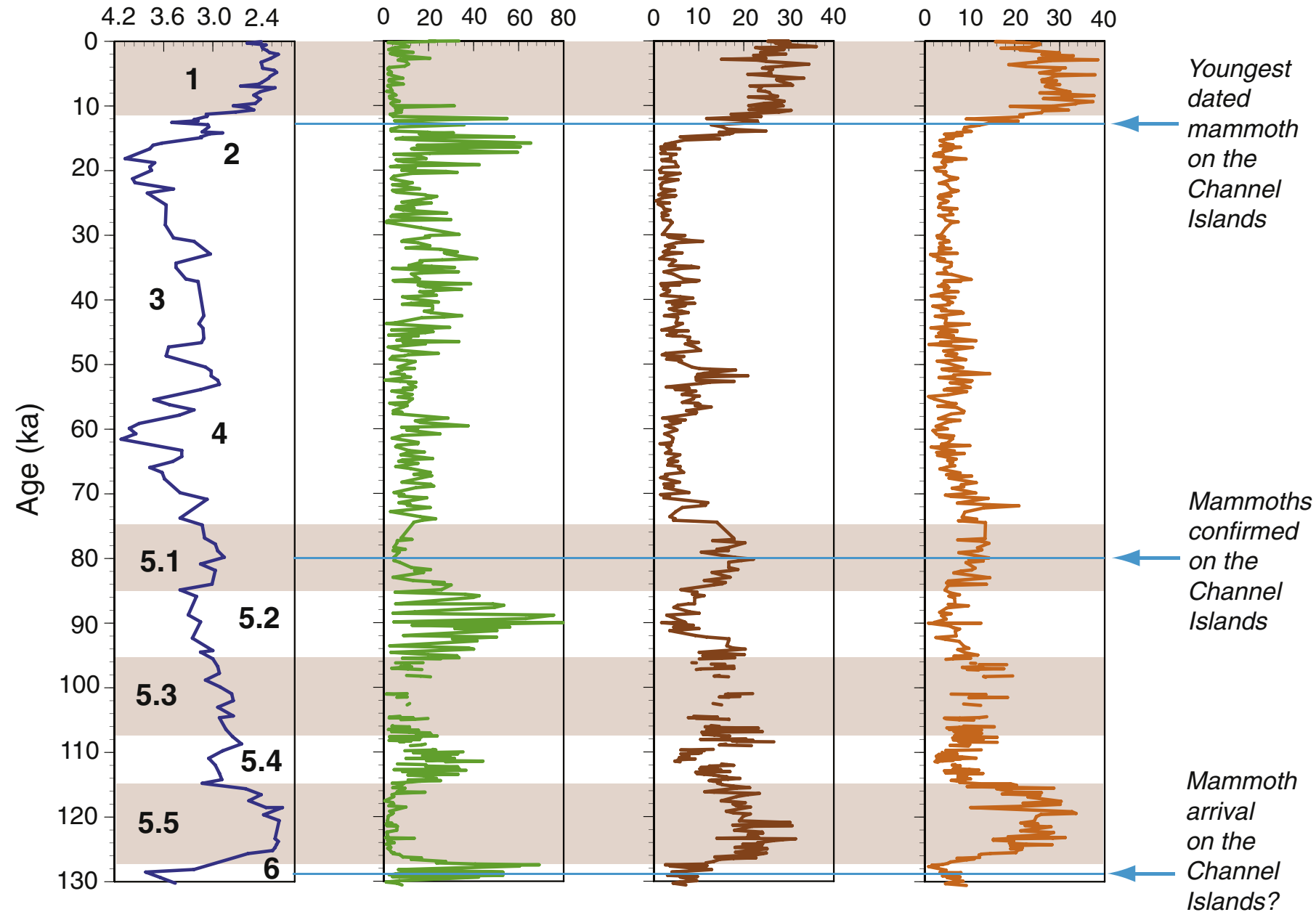

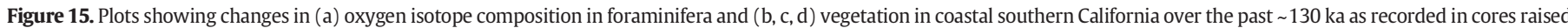

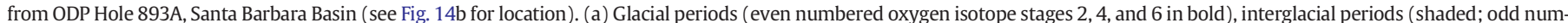

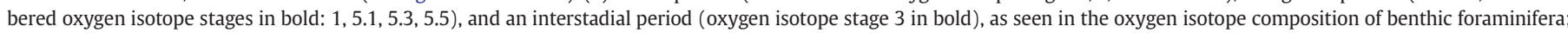

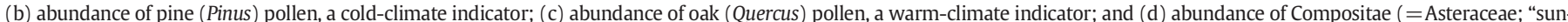

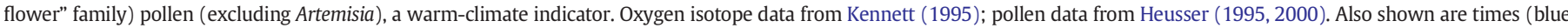

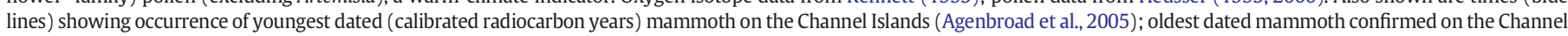
Islands (U-series age; this study); and hypothesized time of arrival of mammoths on the Channel Islands (this study). 
that could adversely affect mammoths would be the breakup of Santarosae into four islands and overall loss of land area, a scenario recently modeled by Reeder-Myers et al. (2015). With post-glacial warming, one could also add vegetation community change (Heusser, $1995,2000)$ and alteration of freshwater sources as stressors on mammoth populations.

An examination of the new evidence for mammoth antiquity on the Channel Islands, presented here, provides a partial test of the hypothesis presented by Rick et al. (2012b) that mammoth extinction on the Channel Islands was due to climate change, ecological disturbance, and loss of land area. Given the findings reported here that mammoth remains are at least as old as $\sim 80 \mathrm{ka}$, it is possible to consider how glacial-interglacial climate and sea level change could have affected mammoths in the penultimate Quaternary climate cycle. If mammoth immigration took place as early as MIS 6, 150 ka, as discussed above, then mammoth colonization of the Channel Islands would have been followed by MIS 5.5, the peak of the last interglacial complex (Fig. 12). Based on records from a number of tectonically stable coastlines, it is known that MIS 5.5 was characterized by a paleo-sea level that was $+6 \mathrm{~m}$ to $+8 \mathrm{~m}$, relative to present (Muhs et al., 2002a, 2011; Dutton and Lambeck, 2012). Thus, in MIS 5.5 time, mammoths would have been faced with a sea level rise more dramatic than during the LGMto-Holocene transition. Mapping of marine terraces that date to MIS 5.5 on the Channel Islands (Pinter et al., 1998; Muhs et al., 2014a) shows that the insular land area during that high-sea stand would have been even more diminished than during the Holocene (Fig. 14). Nevertheless, although island break-up and land loss were more dramatic than during the Holocene, mammoths apparently survived, at least until MIS 5.1. Furthermore, fossil marine mollusk data, marine planktonic data, and pollen data dating to MIS 5.5 from southern California indicate that both marine and terrestrial environments were warmer than present during MIS 5.5 (Fig. 14). Mammoths on the Channel Islands apparently were able to cope with this climate change and its associated vegetation change (Fig. 15), even though it was at least as dramatic as that which mammoths at the Pleistocene-Holocene transition had to contend with.

The long, warm interglacial period of MIS 5.5 would then have been followed by the relatively cool MIS $5.4,5.3$, and 5.2 periods, requiring further adaptation by mammoths back to cool conditions and new changes in vegetation communities (Heusser, 1995, 2000; see Fig. 15). Carbon and nitrogen isotopic evidence from studies of LGM and preLGM M. columbi from Arizona indicates that mammoths may have had a considerable adaptability for food resources, utilizing a variety of sources not only at different points in geologic time, but seasonally, as seen in isotopic variability within individuals (Metcalfe et al., 2011). Thus, changing vegetation communities, from glacial to interglacial climates, need not have been a limiting factor for mammoth survival.

Emphasis is made here that it is not proposed that either humans or an extraterrestrial impact event necessarily had to be the cause of mammoth extinction on the Channel Islands. The point to be raised by the foregoing discussion is simply that in order to appeal to glacialinterglacial climate change, vegetation change, and reduction of island size as explanations for LGM-Holocene extinction of mammoths on the Channel Islands, one must also explain how these factors did not cause such extinctions during the previous glacial-interglacial cycle.

\section{Conclusions}

Field studies on Santa Rosa Island resulted in the discovery of a wellpreserved pygmy mammoth (M. exilis) tusk in deposits of the 1st terrace, confidently dated by U-series methods on coral to $\sim 80 \mathrm{ka}$. A second mammoth tusk, on the other side of Santa Rosa Island, has an age constrained to be at least $\sim 40$ ka but less than $\sim 120 \mathrm{ka}$, based on a combination of radiocarbon and $U$-series dating methods. The new findings presented here establish that mammoths were present on the islands well before the last glacial period. The presence of mammoths on the
Channel Islands at $80 \mathrm{ka}$, a time of relatively high sea level, can best be explained by mammoth immigration (by swimming) during a previous glacial period, when sea level was low and swimming distance from the mainland to the islands was minimal. The most likely times for such immigrations would have been during glacial periods MIS 6 ( $150 \mathrm{ka})$ or 8 $(\sim 250 \mathrm{ka})$. These results support a previous hypothesis that mammoth colonization of the Channel Islands from mainland California could have taken place any time during the Quaternary when paleogeographic conditions were favorable, not necessarily during only the last glacial period. Nevertheless, for mammoth immigration to have taken place, even during glacial periods, sufficient uplift of both the Channel Islands and the California mainland must have taken place such that the mainland-to-island distance was close enough to be within the swimming abilities of mammoths.

Finally, the results presented here challenge the hypothesis that mammoth extinction on the Channel Islands at the PleistoceneHolocene boundary was due to sea-level rise, loss of land area, and post-glacial vegetation change. If mammoths reached the Channel Islands prior to or during the penultimate glacial period (MIS 6), as the results presented here imply, they would have faced much more dramatic sea-level rise, loss of land area, and vegetation change at the start of the last interglacial period (MIS 5.5) compared to the beginning of the Holocene.

\section{Acknowledgments}

We dedicate this paper to the late Donald Lee Johnson (1934-2013), a great friend and pioneer in the study of mammoths on the California Channel Islands. The study was supported by the Climate and Land Use Change Research and Development Program of the U.S. Geological Survey and is a contribution to the "Geologic Records of High Sea Levels" Project. Sincere thanks go to the U.S. National Park Service, Channel Islands National Park, and Kate Faulkner in particular, for field access and logistical support. Mark Senning, Lulis Cuevas, Ed Smith, Sarah Chaney, and Dave Begun (all U.S. National Park Service) were knowledgeable and gracious hosts who assisted with field work during our many trips to Santa Rosa Island. DeAnna Laurel (Colorado State University) assisted with fossil collecting on Santa Rosa Island and Naomi Porat (Geological Survey of Israel) helped collect modern snails on San Miguel Island. George Jefferson (Anza-Borrego Desert State Park, California) kindly offered helpful comments about the antiquity of Mammuthus columbi. Many thanks go to James Dines and Howell Thomas, Natural History Museum of Los Angeles County, for identifying the sea otter remains from the mammoth-bearing marine deposit. Linda Heusser (Lamont-Doherty Earth Observatory) very kindly provided digital files of her pollen data from Santa Barbara Basin, for which we express our thanks. Jeff Pigati, Gene Ellis, Buddy Schweig, and Keith Lucey (all U.S. Geological Survey) made helpful comments on an earlier version of the manuscript, as did two anonymous reviewers and editors David Meltzer and Derek Booth, which we appreciate. Special thanks go to Justin Wilkins, Mammoth Site of Hot Springs, South Dakota, friend and colleague of our late co-author Larry Agenbroad. Because Larry passed away before the final revisions to this paper were made, Justin kindly read the entire manuscript to confirm that the ideas presented here are consistent with what he understood Larry's thoughts to be. Any use of trade, product, or firm names is for descriptive purposes only and does not imply endorsement by the U.S. Government.

\section{References}

Addicott, W.O., 1964. Pleistocene invertebrates from the Dume terrace, western Santa Monica Mountains, California. Bulletin of the Southern California Academy of Sciences 63, 141-150. Agenbroad, L., 1984. New World mammoth distribution. In: Martin, P. Klein, R. (Eds.), Quaternary Extinctions: the Search for a Cause. University of Arizona Press, Tucson, pp. 90-108. Agenbroad, L.D., 1998. New pygmy mammoth (Mammuthus exilis) localities and radiocarbon dates from San Miguel, Santa Rosa, and Santa Cruz Islands, California. In: Weigand, P. (Ed.), Contributions to the Geology of the Northern Channel Islands, Southern California. 
Pacific Section American Association of Petroleum Geologists, Bakersfield, California, pp. 169-175.

Agenbroad, L.D., 2001. Channel Islands (USA) pygmy mammoths (Mammuthus exilis) compared and contrasted with M. columbi, their continental ancestral stock. In: Cavarretta, G., Giolia, F., Mussi, M., Palombo, M.R. (Eds.), La Terra degli Elefanti/The World of Elephants. Proceedings of the 1st International Congress. Consiglio Nazionale delle Ricerche, Roma, pp. $473-475$.

Agenbroad, L.D., 2003. New absolute dates and comparisons for California's Mammuthus exilis. Deinsea 9, 1-16.

Agenbroad, L.D., 2005. North American proboscideans: Mammoths: the state of knowledge, 2003. Quaternary International 126-128, 73-92.

Agenbroad, L.D., 2012. Giants and pygmies: mammoths of Santa Rosa Island, California (USA). Quaternary International 255, 2-8.

Agenbroad, L.D., Morris, D., Roth, L., 1999. Pygmy mammoths Mammuthus exilis from Channel Islands National Park, California (USA). Deinsea 6, 89-102.

Agenbroad, L.D., Johnson, J.R., Morris, D., Stafford Jr., T.W., 2005. Mammoths and humans as late Pleistocene contemporaries on Santa Rosa Island. In: Garcelon, D.K., Schwemm, C.A. (Eds.), Proceedings of the Sixth California Islands Symposium. Institute for Wildlife Studies, Arcata, California, pp. 3-7.

Azzaroli, A., 1981. About pigmy [sic] mammoths of the northern Channel Islands and other island faunas. Quaternary Research 16, 423-425.

Bard, E., Hamelin, B., Fairbanks, R.G., 1990. U-Th ages obtained by mass spectrometry in corals from Barbados: Sea level during the past 130,000 years. Nature 346, 456-458.

Barnosky, A.D., Koch, P.L., Feranec, R.S., Wing, S.L., Shabel, A.B., 2004. Assessing the causes of late Pleistocene extinctions on the continents. Science 306, 70-75.

Berger, R., 1980. Early man on Santa Rosa Island. In: Power, D.M. (Ed.), The California Islands: Proceedings of Multidisciplinary Symposium. Santa Barbara Museum of Natural History, Santa Barbara, California, pp. 73-78.

Berger, R., Orr, P.C., 1966. The fire areas on Santa Rosa Island, II. Proceedings of the National Academy of Sciences 56, 1678-1682.

Cheng, H., Edwards, R.L., Shen, C.-C., Polyak, V.J., Asmerom, Y., Woodhead, J., Hellstrom, J., Wang, Y., Kong, X., Spötl, C., Wang, X., Alexander Jr., E.C., 2013. Improvements in ${ }^{230} \mathrm{Th}$ dating, ${ }^{230} \mathrm{Th}$ and ${ }^{234} \mathrm{U}$ half-life values, and $\mathrm{U}$-Th isotopic measurements by multi-collector inductively coupled plasma mass spectrometry. Earth and Planetary Science Letters 371-372, 82-91.

Clark, J., Mitrovica, J.X., Alder, J., 2014. Coastal paleogeography of the California-OregonWashington and Bering Sea continental shelves during the latest Pleistocene and Holocene: implications for the archaeological record. Journal of Archaeological Science 52, 12-23.

Cushing, J., Daily, M., Noble, E., Roth, V.L., Wenner, A., 1984. Fossil mammoths from Santa Cruz Island, California. Quaternary Research 21, 376-384.

Cutler, K.B., Edwards, R.L., Taylor, F.W., Cheng, H., Adkins, A., Gallup, C.D., Cutler, P.M., Burr, G.S., Bloom, A.L., 2003. Rapid sea-level fall and deep-ocean temperature change since the last interglacial period. Earth and Planetary Science Letters 206, 253-271.

Daulton, T.L., Pinter, N., Scott, A.C., 2010. No evidence of nanodiamonds in Younger-Dryas sediments to support an impact event. Proceedings of the National Academy of Sciences 107, 16043-16047.

Delanghe, D., Bard, E., Hamelin, B., 2002. New TIMS constraints on the uranium-238 and uranium-234 in seawaters from the main ocean basins and the Mediterranean Sea. Marine Chemistry 80, 79-93.

Dutton, A., Lambeck, K., 2012. Ice volume and sea level during the last interglacial. Science 337, 216-219.

Edwards, R.L., Gallup, C.D., Cheng, H., 2003. Uranium-series dating of marine and lacustrine carbonates. Reviews in Mineralogy and Geochemistry 52, 363-405.

Fairbanks, R.G., 1989. A 17,000-year glacio-eustatic sea level record: influence of glacial melting on the Younger Dryas event and deep-ocean circulation. Nature 342, 637-642.

Firestone, R.B., West, A., Kennett, J.P., Becker, L., Bunch, T.E., Revay, Z.S., Schultz, P.H., Belgya, T. Kennett, D.J., Erlandson, J.M., Dickenson, O.J., Goodyear, A.A., Harris, R.S., Howard, G.A., Kloosterman, J.B., Lechler, P., Mayewski, P.A., Montgomery, J., Poreda, R., Darrah, T., Que Hee, S.S., Smith, A.R., Stich, A., Topping, W., Wittke, J.H., Wolbach, W.S., 2007. Evidence for an extraterrestrial impact 12,900 years ago that contributed to the megafaunal extinctions and Younger Dryas cooling. Proceedings of the National Academy of Sciences 104 $16016-16021$.

Flint, R.F., 1971. Glacial and Quaternary Geology. John Wiley and Sons, Inc., New York (892 pp.)

Gallup, C.D., Edwards, R.L., Johnson, R.G., 1994. The timing of high sea levels over the past 200,000 years. Science $263,796-800$.

Graham, R.W., Lundelius Jr., E.L., 1984. Coevolutionary disequilibrium and Pleistocene extinctions. In: Martin, P.S., Klein, R.G. (Eds.), Quaternary Extinctions: a Prehistoric Revolution. University of Arizona Press, Tucson, pp. 211-222.

Grant, L.B., Mueller, K.J., Gath, E.M., Cheng, H., Edwards, R.L., Munro, R., Kennedy, G.L., 1999. Late Quaternary uplift and earthquake potential of the San Joaquin Hills, southern Los Angeles Basin, California. Geology 27, 1031-1034.

Grayson, D.K., Meltzer, D.J., 2002. Clovis hunting and large mammal extinction: a critical review of the evidence. Journal of World Prehistory 16, 313-359.

Grayson, D.K., Meltzer, D.J., 2003. A requiem for North American overkill. Journal of Archaeological Science 30, 585-593.

Gurrola, L.D., Keller, E.A., Chen, J.H., Owen, L.A., Spencer, J.Q., 2014. Tectonic geomorphology of marine terraces: Santa Barbara fold belt, California. Geological Society of America Bulletin 126, 219-233.

Guthrie, R.D., 2004. Radiocarbon evidence of mid-Holocene mammoths stranded on an Alaskan Bering Sea island. Nature 429, 746-749.

Haynes, G., 2013. Extinctions in North America's late glacial landscapes. Quaternary International 285, 89-98.

Herridge, V.L., Lister, A.M., 2012. Extreme insular dwarfism evolved in a mammoth. Proceedings of the Royal Society B. http://dx.doi.org/10.1098/rspb.2012.0671.

Heusser, L.E., 1995. Pollen stratigraphy and paleoecologic interpretation of the 160- k.y. record from Santa Barbara Basin, Hole 893A. In: Kennett, J.P., Baldauf, J.G., Lyle, M. (Eds.), Proceedings of the Ocean Drilling Program. Scientific Results vol. 146. pt. 2, pp. 265-279.

Heusser, L.E., 2000. Rapid oscillations in western North America vegetation and climate during oxygen isotope stage 5 inferred from pollen data from Santa Barbara Basin (Hole 893A). Palaeogeography, Palaeoclimatology, Palaeoecology 161, 407-421.

Holliday, V.T., Surovell, T., Meltzer, D.J., Grayson, D.K., Boslough, M., 2014. The Younger Dryas impact hypothesis: a cosmic catastrophe. Journal of Quaternary Science 29, 515-530.
Howarth, R.J., McArthur, J.M., 1997. Statistics for strontium isotope stratigraphy: a robust LOWESS fit to the marine Sr-isotope curve for 0 to $206 \mathrm{Ma}$, with look-up table for derivation of numeric age. Journal of Geology 105, 441-456.

Johnson, D.L., 1978. The origin of island mammoths and the Quaternary land bridge history of the northern Channel Islands, California. Quaternary Research 10, 204-225.

Johnson, D.L. 1979. Geology, soils, and erosion. In: Power, D.M. (Ed.), Natural Resources Study of the Channel Islands National Monument, California. Santa Barbara Museum of Natural History, Santa Barbara, California, pp. 3.1-3.73.

Johnson, D.L., 1980. Problems in the land vertebrate zoogeography of certain islands and the swimming powers of elephants. Journal of Biogeography 7, 383-398.

Johnson, D.L., 1981. More comments on the northern Channel Islands mammoths. Quaternary Research 15, 105-106.

Junger, A., Johnson, D.L., 1980. Was there a Quaternary land bridge to the northern Channe Islands? In: Power, D.M. (Ed.), The California Islands: Proceedings of Multidisciplinary Symposium. Santa Barbara Museum of Natural History, Santa Barbara, California, pp. 33-39

Kanakoff, G.P., Emerson, W.K., 1959. Late Pleistocene invertebrates of the Newport Bay Area, California. Los Angeles County Museum Contributions in Science, no. 31 (47 pp.).

Kaufman, A., Broecker, W.S., Ku, T.-L., Thurber, D.L., 1971. The status of U-series methods of mollusk dating. Geochimica et Cosmochimica Acta 35, 1115-1183.

Kennedy, G.L., Lajoie, K.R., Wehmiller, J.F., 1982. Aminostratigraphy and faunal correlations of late Quaternary marine terraces, Pacific Coast, USA. Nature 299, 545-547.

Kennedy, G.L., Wehmiller, J.F., Rockwell, T.K., 1992. Paleoecology and paleozoogeography of late Pleistocene marine-terrace faunas of southwestern Santa Barbara County, California. In: Fletcher III, C.H., Wehmiller, J.F. (Eds.), Quaternary Coasts of the United States: Marine and Lacustrine Systems. SEPM (Society for Sedimentary Geology) Special Publication no. 48, pp. 343-361.

Kennett, D.J., Kennett, J.P., West, G.J., Erlandson, J.M., Johnson, J.R., Hendy, I.L., West, A., Culleton, B.J., Jones, T.L., Stafford Jr., T.W., 2008. Wildfire and abrupt ecosystem disruption on California's northern Channel Islands at the Ållerød-Younger Dryas boundary (13.0$12.9 \mathrm{ka})$. Quaternary Science Reviews 27, 2530-2545.

Kennett, D.J., Kennett, J.P., West, A., West, G.J., Bunch, T.E., Culleton, B.J., Erlandson, J.M., Que Hee, S.S., Johnson, J.R., Mercer, C., Shen, F., Sellers, M., Stafford Jr., T.W., Stich, A., Weaver, J.C. Wittke, J.H., Wolbach, W.S., 2009. Shock-synthesized hexagonal diamonds in Younge Dryas boundary sediments. Proceedings of the National Academy of Sciences 106 12623-12628.

Kennett, J.P., 1995. Latest Quaternary benthic oxygen and carbon isotope stratigraphy: hole 893A. In: Kennett, J.P., Baldauf, J.G., Lyles, M. (Eds.), Proceedings of the Ocean Drilling Program. Scientific Results vol. 146. Part 2. Santa Barbara Basin, California, pp. 3-18.

Kennett, J.P., Venz, K., 1995. Late Quaternary climatically related planktonic foraminiferal assemblage changes: Hole 893A, Santa Barbara Basin, California. In: Kennett, J.P., Baldauf, J.G. Lyles, M. (Eds.), Proceedings of the Ocean Drilling Program, Scientific Results vol. 146, Part 2, pp. 281-293.

Kern, J.P., 1977. Origin and history of upper Pleistocene marine terraces, San Diego, California. Geological Society of America Bulletin 88, 1553-1566.

Kuzmin, Y.V., Orlova, L.A., Zolnikov, I.D., 2003. Dynamics of the mammoth (Mammuthus primigenius) population in northern Asia: radiocarbon evidence. Deinsea 9, 221-237.

Lea, D.W., Martin, P.A., Pak, D.K., Spero, H.J., 2002. Reconstructing a 350 ky history of sea level using planktonic $\mathrm{Mg} / \mathrm{Ca}$ and oxygen isotope records from a Cocos Ridge core. Quaternary Science Reviews 21, 283-293.

Lipps, J.E., Valentine, J.W., Mitchell, E., 1968. Pleistocene paleoecology and biostratigraphy, Santa Barbara Island, California. Journal of Paleontology 42, 291-307.

Liscaljet, N., 2012. Napakaliit trompa: new pygmy proboscidean remains from the Cagayan Valley (Phillipines). Quaternary International 276-277, 278-286.

Lister, A., Bahn, P., 2007. Mammoths: Giants of the Ice Age. University of California Press, Berkeley (192 pp.).

Ludwig, K.R., 2001. Users manual for Isoplot/Ex, rev. 2.49. Special Publication No. 1a. Berkeley Geochronology Center, Berkeley, California (55 pp.).

Ludwig, K.R., Simmons, K.R., Szabo, B.J., Winograd, IJ.., Landwehr, J.M., Riggs, A.C., Hoffman, R.J, 1992. Mass-spectrometric ${ }^{230} \mathrm{Th}-{ }^{234} \mathrm{U}-{ }^{238} \mathrm{U}$ dating of the Devils Hole calcite vein. Science 258, 284-287.

Madden, C.T., 1981. Origin(s) of mammoths from northern Channel Islands, California. Quaternary Research 15, 101-104.

Maglio, V.T., 1973. Origin and evolution of the Elephantidae. Transactions of the American Philosophical Society, New Series 63, 1-149.

Martin, P.S., 1967. Prehistoric overkill. In: Martin, P.S., Wright Jr., H.E. (Eds.), Pleistocene Extinc tions: the Search for a Cause. Yale University Press, New Haven, pp. 75-120.

Martin, P.S., 1984. Prehistoric overkill: the global model. In: Martin, P.S., Klein, R.J. (Eds.), Pleistocene Extinctions: a Prehistoric Revolution. University of Arizona Press, Tucson, pp. 354-403.

Martin, P.S., 2005. Twilight of the Mammoths: Ice Age Extinctions and the Rewilding of America. University of California Press, Berkeley (250 pp.).

Martin, P.S., Steadman, D.W., 1999. Prehistoric extinctions on islands and continents. In: MacPhee, R.D.E. (Ed.), Extinctions in Near Time, Causes, Contexts, and Consequences. Kluwer Academic/Plenum Publishers, New York, pp. 17-55.

Martinson, D.G., Pisias, N.G., Hays, J.D., Imbrie, J., Moore Jr., T.C., Shackleton, N.J., 1987. Age dating and the orbital theory of the ice ages: development of a high-resolution 0 to 300,000-year chronostratigraphy. Quaternary Research 27, 1-29.

McDaniel Jr., G.E., Jefferson, G.T., 2006. Mammoths in our midst: the proboscideans of AnzaBorrego Desert State Park $®$, southern California, USA. Quaternary International 142-143, 124-129.

Meltzer, D.J., Holliday, V.T., Cannon, M.D., Miller, D.S., 2014. Chronological evidence fails to support claim of an isochronous widespread layer of cosmic impact indicators dated to 12,800 years ago. Proceedings of the National Academy of Sciences 111, E2162-E2171.

Metcalfe, J.Z., Longstaffe, F.J., Ballenger, J.A.M., Haynes Jr., C.V., 2011. Isotopic paleoecology o Clovis mammoths from Arizona. Proceedings of the National Academy of Sciences 108 17916-17920.

Muhs, D.R., Miller, G.H., Whelan, J.F., Kennedy, G.L., 1992. Aminostratigraphy and oxygen isotope stratigraphy of marine-terrace deposits, Palos Verdes Hills and San Pedro areas, Los Angeles 
County, California. In: Fletcher III, C.H., Wehmiller, J.F. (Eds.), Quaternary Coasts of the United States: Marine and Lacustrine Systems. SEPM (Society for Sedimentary Geology) Special Publication no. 48, pp. 363-376.

Muhs, D.R., Simmons, K.R., Kennedy, G.L., Rockwell, T.K., 2002a. The last interglacial period on the Pacific Coast of North America: timing and paleoclimate. Geological Society of America Bulletin 114, 569-592.

Muhs, D.R., Simmons, K.R., Steinke, B., 2002b. Timing and warmth of the last interglacial period: new U-series evidence from Hawaii and Bermuda and a new fossil compilation for North America. Quaternary Science Reviews 21, 1355-1383.

Muhs, D.R., Simmons, K.R., Kennedy, G.L., Ludwig, K.R., Groves, L.T., 2006. A cool eastern Pacific Ocean at the close of the last interglacial complex. Quaternary Science Reviews 25, 235-262.

Muhs, D.R., Simmons, K.R., Schumann, R.R., Groves, L.T., DeVogel, S., Patterson, D., Richards, D.V 2010. Last interglacial sea-level history on Santa Barbara and Anacapa Islands, Channe Islands National Park, California. Geological Society of America Abstracts with Programs $42(5), 563$.

Muhs, D.R., Simmons, K.R., Schumann, R.R., Halley, R.B., 2011. Sea-level history of the past two interglacial periods: new evidence from U-series dating of reef corals from south Florida. Quaternary Science Reviews 30, 570-590.

Muhs, D.R., Simmons, K.R., Schumann, R.R., Groves, L.T., Mitrovica, J.X., Laurel, D., 2012. Sea-level history during the last interglacial complex on San Nicolas Island, California: implications for glacial isostatic adjustment processes, paleozoogeography and tectonics. Quaternary Science Reviews 37, 1-25.

Muhs, D.R., Simmons, K.R., Schumann, R.R, Groves, LT, DeVogel, S.B., Minor, S.A., Laurel, D. 2014a. Coastal tectonics on the eastern margin of the Pacific Rim: Late Quaternary sealevel history and uplift rates, Channel Islands National Park, California, USA. Quaternary Science Reviews 105, 209-238.

Muhs, D.R., Groves, L.T., Schumann, R.R., 2014b. Interpreting the paleozoogeography and se level history of thermally anomalous marine terrace faunas: a case study from the last interglacial complex of San Clemente Island, California. Monographs of the Western North American Naturalist 7, 82-108.

Orr, P.C., 1960. Late Pleistocene marine terraces on Santa Rosa Island, California. Geologica Society of America Bulletin 71, 1113-1120.

Orr, P.C., 1967. Geochronology of Santa Rosa Island, California. In: Philbrick, R.N. (Ed.), Proceedings of the Symposium on the Biology of the California Islands. Santa Barbara Botanic Garden, Santa Barbara, California, pp. 317-325.

Orr, P.C., 1968. Prehistory of Santa Rosa Island. Santa Barbara Museum of Natural History, Santa Barbara, California.

Orr, P.C., Berger, R., 1966. The fire areas on Santa Rosa Island, California. Proceedings of the National Academy of Sciences 56, 1409-1416.

Palombo, M.R., 2001. Endemic elephants of the Mediterranean Islands: knowledge, problems and perspective. In: Cavarretta, G., Giolia, F., Mussi, M., Palombo, M.R. (Eds.), La Terr degli Elefanti/The World of Elephants. Proceedings of the 1st International Congress. Consiglio Nazionale delle Ricerche, Roma, pp. 486-491.

Palombo, M.R., 2007. How can endemic proboscideans help us understand the "island rule"? A case study of Mediterranean islands. Quaternary International 169-170, 105-124.

Palombo, M.R., Rozzi, R., 2013. Dwarfing and gigantism in Quaternary vertebrates. In: Elias, S. Mock, C. (Eds.), Encyclopedia of Quaternary Sciences. Elsevier, Amsterdam, pp. 733-747.

Peltier, W.R., Fairbanks, R.G., 2006. Global glacial ice volume and Last Glacial Maximum duration from an extended Barbados sea level record. Quaternary Science Reviews 25, 3322-3337.

Pigati, J.S., Quade, J., Wilson, J., Jull, A.J.T., Lifton, N.A., 2007. Development of low-background vacuum extraction and graphitization systems for ${ }^{14} \mathrm{C}$ dating of old $(40-60 \mathrm{ka})$ samples. Quaternary International 166, 4-14.

Pigati, J.S., Rech, J.A., Nekola, J.C., 2010. Radiocarbon dating of small terrestrial gastropod shells in North America. Quaternary Geochronology 5, 519-532.

Pigati, J.S., McGeehin, J.P., Muhs, D.R., Bettis III, E.A., 2013. Radiocarbon dating late Quaternary loess deposits using small terrestrial gastropod shells. Quaternary Science Reviews 76, 114-128.

Pigati, J.S., McGeehin, J.P., Skipp, G.L., Muhs, D.R., 2014. Evidence of repeated wildfires prior to human occupation on San Nicolas Island, California. Monographs of the Western North American Naturalist 7, 35-47.

Pinter, N., Lueddecke, S.B., Keller, E.A., Simmons, K.R., 1998. Late Quaternary slip on the Santa Cruz Island fault, California. Geological Society of America Bulletin 110, 711-722.

Pinter, N., Scott, A.C., Daulton, T.L, Podoll, A., Koeberl, C., Anderson, R.S., Ishman, S.E., 2011. The Younger Dryas impact hypothesis: a requiem. Earth-Science Reviews 106, 247-264.

Potter, E.-K., Lambeck, K., 2003. Reconciliation of sea-level observations in the Western North Atlantic during the last glacial cycle. Earth and Planetary Science Letters 217, 171-181.

Potter, E.-K., Esat, T.M., Schellmann, G., Radtke, U., Lambeck, K., McCulloch, M.T., 2004. Suborbital-period sea-level oscillations during marine isotope substages $5 \mathrm{a}$ and $5 \mathrm{c}$. Earth and Planetary Science Letters 225, 191-204.

Poulakakis, N., Parmakelis, A., Lymberakis, P., Mylonas, M., Zouros, E., Reese, D.S., Glaberman, S. Caccone, A., 2006. Ancient DNA forces reconsideration of evolutionary history of Mediterranean pygmy elephantids. Biology Letters 2, 451-454.

Reeder-Myers, L, Erlandson, J.M., Muhs, D.R., Rick, T.C. 2015. Sea level, paleogeography, and archeology on California's Northern Channel Islands. Quaternary Research 83, 263-272.

Reimer, P., Bard, E., Bayliss, A., Beck, J., Blackwell, P., Ramsey, C.B., Grootes, P., Guilderson, T., Haflidason, I., Hajdas, I., et al., 2013. IntCal13 and Marine13 radiocarbon age calibration curves, 0-50,000 years cal BP. Radiocarbon 55, 1869-1887.
Rick, T.C., Wah, J.S., Erlandson, J.M., 2012a. Re-evaluating the origins of late Pleistocene fire areas on Santa Rosa Island, California, USA. Quaternary Research 78, 353-362.

Rick, T.C., Hofman, C.A., Braje, T.J., Maldonado, J.E., Sillett, T.S., Danchisko, K., Erlandson, J.M., 2012b. Flightless ducks, giant mice and pygmy mammoths: Late Quaternary extinctions on California's Channel Islands. World Archaeology 44, 3-20.

Rohling EJ Grant, K., Bolshaw, M., Roberts, A.P. Siddall, M., Hemleben, Ch., Kucera, M., 2009. Antarctic temperature and global sea level closely coupled over the past five glacial cycles. Nature Geoscience 2, 500-504

Rohling, E.J., Braun, K., Grant, K., Kucera, M., Roberts, A.P., Siddall, M., Trommer, G., 2010. Comparison between Holocene and Marine Isotope Stage-11 sea-level histories. Earth and Planetary Science Letters 291, 97-105.

Roth, V.L., 1993. Dwarfism and variability in the Santa Rosa Island mammoth (Mammuthus exilis): an interspecific comparion of limb-bone sizes and shapes in elephants. In: Hochberg, F.G. (Ed.), Third California Islands Symposium: Recent Advances in Research on the California Islands. Santa Barbara Museum of Natural History, Santa Barbara, California, pp. 433-442

Sandom, C., Faurby, S., Sandel, B., Svenning, J.-C., 2014. Global late Quaternary megafauna extinctions linked to humans, not climate change. Proceedings of the Royal Society B 281 (20133254. http://dx.doi.org/10.1098/rspb.2013.3254).

Sarna-Wojcicki, A.M., Lajoie, K.R., Yerkes, R.F., 1987. Recurrent Holocene displacement on the Javon Canyon fault-a comparison of fault-movement history with calculated recurrence intervals. U.S. Geological Survey Professional Paper 1339, 125-135 (Chapter 8).

Schellmann, G., Radtke, U., 2004. A revised morpho- and chronostratigraphy of the Late and Middle Pleistocene coral reef terraces on southern Barbados (West Indies). Earth-Science Reviews 64, 157-187.

Schwarcz, H.P., Blackwell, B.A., 1992. Archaeological applications. In: Ivanovich, M., Harmon, R.S. (Eds.), Uranium-series Disequilibrium: Applications to Earth, Marine and Environmental Sciences, 2nd edition Clarendon Press, Oxford, pp. 511-552.

Stuiver, M., Reimer, P.J., 1993. Extended ${ }^{14} \mathrm{C}$ database and revised CALIB radiocarbon calibration program. Radiocarbon 35, 215-230.

Takahashi, K., Chang, C.H., Cheng, Y.N., 2001. Proboscidean fossils from the Japanese Archipelago and Taiwan islands and their relationship with the Chinese mainland. In: Cavarretta, G., Giolia, F., Mussi, M., Palombo, M.R. (Eds.), La Terra degli Elefanti/The World of Elephants. Proceedings of the 1st International Congress. Consiglio Nazionale delle Ricerche, Roma, pp. 148-151.

Thompson, W.G., Spiegelman, M.W., Goldstein, S.L., Speed, R.C., 2003. An open-system model for U-series age determinations of fossil corals. Earth and Planetary Science Letters 210, 365-381.

Tikhonov, A., Agenbroad, L., Vartanyan, S., 2003. Comparative analysis of the mammoth populations on Wrangel Island and the Channel Islands. Deinsea 9, 415-420.

Toscano, M.A., Lundberg, J., 1999. Submerged Late Pleistocene reefs on the tectonically-stable S.E. Florida margin: high-precision geochronology, stratigraphy, resolution of Substage 5a sea-level elevation, and orbital forcing. Quaternary Science Reviews 18, 753-767.

Valentine, J.W., 1962. Pleistocene molluscan notes. 4. Older terrace faunas from Palos Verdes Hills, California. Journal of Geology 70, 92-101.

Valentine, J.W. Lipps, J.H. 1967. Late Cenozoic history of the southern California Islands. In: Philbrick, R.N. (Ed.), Proceedings of the Symposium on the Biology of the California Islands. Santa Barbara Botanic Garden, Santa Barbara, California, pp. 21-35.

Vartanyan, S.L., Arslanov, K.A., Karhu, J.A., Possnert, G., Sulerzhitsky, L.D., 2008. Collection of radiocarbon dates on the mammoths (Mammuthus primigenius) and other genera of Wrangel Island, northeast Siberia, Russia. Quaternary Research 70, 51-59.

Vedder, J.G., Norris, R.M., 1963. Geology of San Nicolas Island California. U.S. Geological Survey Professional Paper 369, 1-65.

Veltre, D.W., Yesner, D.R., Crossen, K.J., Graham, R.W., Coltrain, J.B., 2008. Patterns of faunal extinction and paleoclimatic change from mid-Holocene mammoth and polar bear remains, Pribilof Islands, Alaska. Quaternary Research 70, 40-50.

Weaver, D.W., Doerner, D.P., Nolf, B., 1969. Geology of the Northern Channel Islands. American Association of Petroleum Geologists and Society of Economic Paleontologists and Mineralogists, Pacific Sections, Special Publication, 200 pp., 3 geologic maps, scale 1:24,000.

Webb, S.D., Dudley, J.P., 1995. Proboscidea from the Leisey Shell Pits, Hillsborough County, Florida. Bulletin of the Florida Museum of Natural History 37 (II), 645-660.

Webb, S.D., Morgan, G.S., Hulbert Jr., R.C., Jones, D.S., MacFadden, B.J., Mueller, P.A., 1989. Geochronology of a rich early Pleistocene vertebrate fauna, Leisey Shell Pit, Tampa Bay, Florida. Quaternary Research 32, 96-110.

Wehmiller, J.F. Simmons, K.R., Cheng, H., Edwards, R.L., Martin-McNaughton, J., York, L.L. Krantz, D.E., Shen, C.-C., 2004. Uranium-series coral ages from the US Atlantic Coastal Plain-the "80 ka problem" revisited. Quaternary International 120, 3-14.

Wendorf, M., 1982. The fire areas of Santa Rosa Island: an interpretation. North American Archaeologist 3, 173-180.

Wenner, A.M., Johnson, D.L., 1980. Land vertebrates on the California Channel Islands: sweepstakes or bridges? In: Power, D.M. (Ed.), The California Islands: Proceedings of Multidisciplinary Symposium. Santa Barbara Museum of Natural History, Santa Barbara, California, pp. $497-530$. 